\title{
反復性膀腅炎の検討（続）
}

\begin{tabular}{|c|c|c|c|c|}
\hline 央鉄 & 院泌尿器科 & 清 & 島 & 茂 \\
\hline$"$ & 産婦人科 & 長 & 野 & 正 \\
\hline " & 中央㭘查室 & 伊 & 藤 & 機 \\
\hline
\end{tabular}

\section{CLINICAL STUDY OF RECURRENT BACTERIAL CYSTITIS}

\section{A SUPPLEMENTARY STUDY}

\author{
Shigetoshi Kiyoshima, Masao Nagano and Kiichi Ito \\ Division of Urology, Division of Obstetrics and Gynecology, Clinical and Reseach \\ Laboratories, The Central Hospital of Japan National Railways in Tokyo
}

In the previous study, the re-construction of normal vaginal flora which was made up with artificial colonization of cultured viable Lactobacilli, was proved to be effective in preventing the recurrent urinary tract infection, and then it was clarified that the acquired ill disposition, easily falling in recurrent urinary infection, in preclimacteric females resulted from the establishment of pathogenic bacterial flora on their vaginal mucosa.

The procedure, the colonization of viable Lactobacilli on vaginal mucosa, had resulted in some 80 to $90 \%$ effectiveness in preventing the recurrent urinary infection for from 14 to 34 months' period in each of 17 cases successfully tried out. There were 9 cases out of them, who were without the persistence of Lactobacilli from their vagina in the above-mentioned follow up/or and further 12 months' periods, and their fates for urinary tract infection were as followings,

a) 2 cases had re-acquired the ill disposition,

b) 2 cases had entirely been free from the urinary tract infection for 46 and 38 months respectively since the completion of the procedure,

c) 4 cases had suffered from one or 2 single episode infections through the follow-up period from 24 to 38 months,

d) the last one case had been free from infection in the first 20 months, and then suffered 2 infections in the last 6 months through her 37 months' follow up period, and the effectiveness of the procedure was suspended.

The well being 4 cases out of $6(b+c)$, had carried uniformly some coryneform Gram negative small rods in their vaginal flora as predominant organism, and one case out of the remaining 2 cases carried a few numbers of Esch. coli, and the last case (d) had also carried a Gram negative small rod, which was identified as Haemophilus parainfluenzae, in recent 9 months as a predominant organism.

For the hope of discovering some predominant organisms which did not cause any urinary infections instead of Lactobacilli which were supposed to be missing in the postmenopausal stage, we surveyed about the normal vaginal bacteria above all the predominant ones in 40 normal females who visited our gynecological clinic for the cytological examination of cancer. They were 32 to 62 years of age and more than $60 \%$ of them were in the 5 th decade. The vaginal pool secretions were subjected to cytological and bacteriological examinations and also $\mathrm{pH}$ of the secretions were determined by a paper method using Brom cresol green as an indicator.

The results of the survey suggested that, in "normal" females the predominant organisms in vaginal bacterial flora were only consisted from Lactobacilli and some Gram negative small rods, presumably so-called Haemophilus vaginalis (Gardner \& Dukes, 1955), and their predominacies in vaginal flora 
changed from the former to the latter alternately correlating with the ovarian activities representative of premenopausal and postmenopausal situations, and then the latter gradually disappeared with aging of the hosts.

For the last condition of vaginal mucosa, we called temporarily "scanty material stage" of vaginal mucosa, and took the condition which was also represented as carrying scanty vaginal secretion or/and only a few cell and bacterial components, for showing a consumed circumstance for bacterial growth, even if there were any urinary pathogens, did not permit them sufficient growth enough to initiate some infective diseases.

Out of our patients, subjected to the procedure, and missing the Lactobacilli thereafter, and not yet having any re-acquistions of the ill disposition, there were some who had the coryneform Gram negative small rod as predominant organism in their vaginal flora, and there was one who had only a few numbers of Esch. coli as an inhabitant persisted.

For these "normal" imitating states observed in our patients, our understanding was that, the procedure, colonizing viable Lactobacilli on vaginal mucosa, resulted in really normal vaginal bacterial processes not only in premenopausals but also in postmenopausals, and that was the reason why these Lactobacilli missing subjects had been free from the ill disposition.

The coryneform Gram negative small rod, possible Haemophilus vaginalis, as the predominant organism, despite the second acid producer on vaginal mucosa, seemed not to inhibit the other commrnsals actively, because there were more numerous bacterial growths observed than in the Lactobacilli predominant mucosa. The predominancy of the former seemed to be induced by the foregoing Lactobacilli predominancy and following low $\mathrm{pH}$ circumstance, and a disturbance of this bacterial alternation, which was suspected to occur from the abuse of some potential broad spectrum antibiotics or from the local carriages of some infections (trichomonadal, candidal etc) or malignancies. This would result in the pathogenic bacterial colonization and their persistence in vaginal flora and that was the reason of acquistion of the ill disposition among the preclimacteric females who maintained some ovarian and reproductive activities at that time.

Therefore, the following conclusion for applicating the procedure, colonizing viable Lactobacilli on vaginal mucosa for the purpose of prevention of recurrent urinary tract infection, was made; the procedure must be indicated to the premenopausal females who carried pathogenic vaginal bacterial flora until their menopausal stage repeatedly and could be discontinued when the predominancy of coryneform Gram negative small rods, possibly Haemophilus vaginalis, was observed or the subjects were suspected to be in their "scanty material stage".

\section{緒 言}

単純な尿路感染症に反復罹患する患者の臨床的観察を 介して，それが更年前期の女性に多くみられ，起炎菌に ついては桿菌によるものばかりで, その際の尿分離菌に 対して患者血清中にそれらを凝集する抗体の存在が屡々 みられたことからそのような細菌が患者の体内に常在す る可能性を考元, その habitat として治療や処置につい ての $2 \sim 3$ の錯誤をかさねた結果胵粘膜に想到し, 該部 に括ける病的細菌叢の成立が反復性尿路感染症罹患の獲 得性素因 (以下反復性尿路感染素因之略称する) と関係 があることを確かめ, 反復感染阻止の目的で尿路感染症 の治療に併行して腟内殺菌と培養 Döderlein 乳酸桿菌 (以下乳酸菌之略称) 生菌の胵粘膜移植を行つて胵内細 菌叢の正常化を試み，所期の効果を収めることができ
た ${ }^{14)}$.引続きその対象17例について尿路感染生起飞関す る予後の追跡を行つているが, 乳酸菌移植の試みをはじ めてから 3 年弱を経過した昭和 50 年 3 月現在の成績を第 1 回沖縄地方会で報告した ${ }^{15)}$. その要旨の 1 は, 移植乳酸 菌の胵粘膜生着を確認してから個々の症例について14 34カ月を経過した期間中に尿路感染が全く終熄して再罹 患をみない者 7, 1 回だけ感染をみた者 7, 2 回感染症 を発した者 $1 ， 3$ 回以上尿路感染症を反復した者 2 で， 反復性尿路感染症罹患阻止の効果について有効の基準を 6 力月間またはそれ以上の再罹患阻止においた場合は $14 / 17(82.4 \%)$, 仮令再罹患はあつてもその後 6 カ月間 以上尿路感染症罹患を免れた場合，その再罹患は反復性 尿路感染素因を反映するものではなかつたと理解し，感 染症を発したにも不拘有効経過をとつたと評価した場合 
の有効率は13/14（92.7\%，不定 2 ，連絡杜絶 1)，更に それ以上の期間を経過するらちにある時点から乳酸菌の 胵粘膜持続が喪われ，年回 3 回以上の尿路感染症罹患を みるようになつた，換言すれば反復性尿路感染素因が復 旧した事実を示す真の意味での無効（転化）症例を前提 にして逆に有効率を計算すると13/15（86.7\%，不定 1， 連絡杜絶 1) となつた。 以上 3 つの有効判定基準は相互 に無関係で，導きだされた数字も亦相互に異質の内容を 含んで拈り，有効率としてあげた数值のちがいは追跡期 間の長さに応じた有効率の推移を示すものではなく， “反復性”と云う術語の定義に基いてきまる性質のもの で尿路感染症に関して不用意に使われている“反復性” と云う術語に明確な定義が与兄られるよう提言した．要 旨の 2 は, 対象例の個々の経過をみてゆくと, 乳酸菌持 続の衰われたことと反復性尿路感染素因の復旧とが相関 する例がある反面，ある時点以後明らかに乳酸菌持続が 喪われているにる不拘反復性尿路感染症罹患を免れて経 過している例の存在する事実があり，その様な症例では 略々共通して乳酸菌以外のある種細菌が胵内細菌丵にお いて新たに predominancy を確立している情況がみられ た。そして否らざる症例に拈いては現在良好な経過をと つてはいても近い将来にいらうれ反復性尿路感染素因が復 旧することを予測するというものであつた．

本論文はその報告の時点から更に 1 年間の予後を追跡 調査し，前年度に有効率としてあげた数值を検証すると 共に，別に正常女性を対象にその䐋粘膜細菌の動態を観 察して腟内細菌叢に括ける生理的な predominant organisms の推移をみいだし，その知見を乳酸菌移植 series の症例にみられた腔粘膜細菌の交代現象にてらして，そ の尿路感染症罹患に関する予後との関係づけを行い，以 て反復性尿路感染素因を除去する目的で適用した乳酸菌 生菌移植の意義を一層明確にせんとするものである.

\section{乳酸菌移植が反復性尿路感染素因除去に及ぼす効果の}

\section{経年的観察}

対象の17症例は前回の報告 ${ }^{14)}$ の第13表に一括表示した ものと同じである，その表では予後の最終調査は昭和 49 年 3 月現在のものであるが今回表示したもの（第 1 表） は，その一部を再録すると共に昭和50年 3 月および昭和 51 年 3 月の調查結果を追記して夫々の時点に和ける有効 率が算出できるように配慮した。な扢この表では年齢の 項に患者の生年を記載した。第 2 表は昭和 50 年 3 月現在 の予後調査に打乳酸菌移植が反復性尿路感染素因の 除去効果を緒言でのべたように有効判定基準の種々のと
第 1 表 浮酸菌移植成立症例の尿路感染症汇関する 予後 (17症例)

\begin{tabular}{|c|c|c|c|c|c|c|c|}
\hline \multicolumn{3}{|c|}{ 症 例 } & \multirow{2}{*}{$\begin{array}{l}\text { 乳酸菌生着日 } \\
\text { と確㑇方法 }\end{array}$} & \multicolumn{3}{|c|}{ 尿路感染症に関する予後 } & \multirow{2}{*}{$\begin{array}{l}\text { 経過 } \\
\text { 月数 }\end{array}$} \\
\hline $\mathrm{Na}$ & 名 & 生年 & & 昭49. 3 & 昭50. 3 & 昭51. 3 & \\
\hline 2 & $\mathrm{~s}$ & 昭 6 & 47. 5.16. 鏡 & 感染なし & 感染なし & 感染なし & 46 \\
\hline 4 & $\mathrm{~S}$ & 昭 12 & 47. 6. 6. 鏡 & 感染なし & 感染なし & 感染なし & 45 \\
\hline 5 & $\mathrm{M}$ & 大 14 & 47. 6.27 . 培 & 48. 9.25. C & 感染なし & 感染なし & 45 \\
\hline 6 & $\mathrm{~K}$ & 昭 5 & 47. 9.12 . 培 & 48. 1. C & \multicolumn{2}{|c|}{ 連絡杜絶 } & 18 \\
\hline 7 & $\mathrm{~s}$ & 大11 & 47.12.15. 鏡 & 感染なし & \multicolumn{2}{|l|}{ 49.12. 死亡 } & 23 \\
\hline 9 & $\mathrm{~S}$ & 大11 & 48. 1.30. 培 & 48.11. C & C: $4 \times$ & $C: 2 \times$ & 37 \\
\hline 10 & $\mathrm{H}$ & 吸21 & 48.10.2. 培 & 感染なし & 感染なし & 50.6. C: $2 \times$ & 29 \\
\hline \multirow{2}{*}{11} & \multirow{2}{*}{ Y } & \multirow{2}{*}{ 㑼10 } & 48.2.20. 培 & 感染なし & 49.11. C & 50.12.1.C & \multirow{2}{*}{37} \\
\hline & & & & & & 51. 1.24. C & \\
\hline 12 & $\mathrm{~s}$ & 昭 4 & 48. 1.16. 培 & 48. 8.1. C & 感染なし & $50.6 .9 . \mathrm{C}$ & 38 \\
\hline 13 & $\mathrm{~N}$ & 昭 6 & 48. 1.10 . 鏡 & 感染なし & 感染なし & 感染なし & 38 \\
\hline 14 & I & 昭21 & 48. 1.26. 鏡 & 49. 1.19. C & 感染なし & 感染なし & 38 \\
\hline 15 & $\mathrm{~T}$ & 昭 5 & 48. 8.17 . 培 & 感染なし & 感染なし & 感染なし & 31 \\
\hline \multirow{2}{*}{16} & \multirow{2}{*}{$\mathrm{O}$} & \multirow{2}{*}{ 昭 7} & 48. 7.26 . 镜 & 49. 1.29. C & 49. $5 . \mathrm{C}$ & 50.9.5. C & \multirow{2}{*}{31} \\
\hline & & & & & & 50.10. C & \\
\hline 17 & $\mathrm{I}$ & 昭 8 & 48. 7.6 . 培 & 感染なし & 感染なし & 連絡杜絶* & 19 \\
\hline \multirow{4}{*}{18} & \multirow{4}{*}{$\mathrm{O}$} & \multirow{4}{*}{ 略 3} & 49. 9.13 培 & 感染なし & 49. 6.12. P & & \multirow{4}{*}{31} \\
\hline & & & & & 50.1.12. P & & \\
\hline & & & & & 50. 3.25. C & 50.12.31. C & \\
\hline & & & 51.1.15. 培 (2) & & & & \\
\hline \multirow{2}{*}{19} & \multirow{2}{*}{$M$} & \multirow{2}{*}{ 昭 4} & 48.12.21. 培 & 49. 2. 5. C & & & \multirow{2}{*}{26} \\
\hline & & & 49.2.28培(2) & & 感染なし & 感染なし & \\
\hline \multirow{3}{*}{20} & \multirow{3}{*}{$\mathrm{T}$} & \multirow{3}{*}{ 昭 2} & 49.1.7. 培 & 感染なし & 49. 4.15. C & & \multirow{3}{*}{26} \\
\hline & & & 49.5.2. 培(2) & & & 50. 8.18. C & \\
\hline & & & 50.10 .3 . 培 $(3)$ & & & & \\
\hline
\end{tabular}

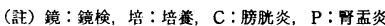

*51:7.1柋染なし(校正時追加)

り方に応じて算出したものである。

はじめの 6 カ月間の尿路感染症再罹患阻止を以て有効 であるとした場合の有効率 $82.4 \%$ は昭和 49 年 3 月現在で 試算すると $87.5 \%$ (14/16，不定 1) となるべきものの 修正值で, その数值は昭和51年 3 月の時点でも修正され ることはない，再罹患後 6 力月間以内に再々罹患があつ たか否かによつて有効を定義した場合の有効率は昭和50 年 3 月の調査段階で算出可能となり，その数值は $92.7 \%$ であるが昭和51年 3 月調査による知見を加味すると当時 の不定 2 症例中の 1 例はのちに有効に転化することが知 られるのでその数值は93.3\%(14/15, 不定 1, 連絡杜 絶 1 ）に修正される．ただしこの判定方法は再々罹患以 後の尿路感染の有無を前提にしていないので昭和50年 3 月の時点で既にそれが不備な方法であることを暴露して いる. 即ちその時点で胵粘膜の乳酸菌持続が喪われ，か つ年間 3 回以上の尿路感染症反復罹患をみる真の意味で の無効化症例が存在しているからである．このあとの意 味で試算した有効率 $86.7 \%$ の数値を, 当時は他の乳酸菌 持続が䚻われ，かつ特定の細菌による predominancy が みられね症例 (No. 12) が無効例に転化するものと考 
第 2 表 乳酸菌移植症例の尿路感染症に関する予後（昭和50年 3 月現在）

\begin{tabular}{|c|c|c|c|c|c|c|}
\hline \multirow{2}{*}{ 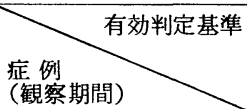 } & \multicolumn{2}{|c|}{$\begin{array}{l}\text { 始めの6 } 6 \text { 月間 } \\
\text { 感 染 }\end{array}$} & \multicolumn{2}{|c|}{ 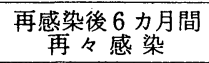 } & \multicolumn{2}{|c|}{$\begin{array}{c}\text { 再感染後 6力月以降 } \\
\text { 反復性感染素因 }\end{array}$} \\
\hline & なし & あり & なし & あり & なし & 復 旧 \\
\hline $\mathrm{A} \begin{array}{c}\text { 乳酸菌移植 } \\
\text { 感染あ } \\
(14 \sim 33 \text { 月 })\end{array}: 10$ & 7 & $3^{*}$ & 6 & $1^{*}$ & 6 & $2^{*}$ \\
\hline 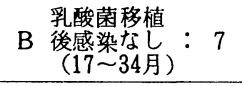 & 7 & & (7) & & (7) & \\
\hline \multirow{2}{*}{ 合 } & \multirow{2}{*}{14} & \multirow{2}{*}{3} & 13 & 1 & 13 & 2 \\
\hline & & & \multicolumn{2}{|c|}{ 不定 2 , 連絡杜絶 1} & \multicolumn{2}{|c|}{ 不定 1 ，連絡杜絶 1} \\
\hline
\end{tabular}

同上結果に基く有効率

\begin{tabular}{|c|c|c|c|c|c|c|}
\hline 昭50. 3. 現在 & \multicolumn{2}{|c|}{$14 / 17: 82.4 \%$} & \multicolumn{2}{|c|}{$13 / 14: 92.7 \%$} & \multicolumn{2}{|c|}{$13 / 15: 86.7 \%$} \\
\hline \multirow{2}{*}{$\begin{array}{l}\text { 49. 3. 現在で試算 } \\
(\mathrm{A}: 7, \mathrm{~B}: 10)\end{array}$} & 14 & 2 & & & & \\
\hline & \multicolumn{2}{|c|}{ 87.5\%(不定 1) } & & & & \\
\hline \multirow{2}{*}{$\begin{array}{c}\text { 51. 3. 知見による } \\
\text { 修 正値 }\end{array}$} & \multirow{2}{*}{\multicolumn{2}{|c|}{$\begin{array}{c}14 / 17: 82.4 \% \\
(\mathrm{~A}: 11, \mathrm{~B}: 6)\end{array}$}} & 14 & 1 & 14 & 2 \\
\hline & & & 93.39 & など 2) & \multicolumn{2}{|c|}{$87.5 \%(\text { 連なし } 1)^{* *}$} \\
\hline
\end{tabular}

*すべて相互に異る個人である ${ }^{* *} 51.7 .1$ 反復感染素因なきことを確認（校正時追加）

え，より低值に修正されることを予想したが，昭和51年 3 月の調査でこの症例は依然として有効の経過をとつて 扣り，当時経年不足で効果不定と評価された 1 例が有効 例となり，別に新たに無効に転化した症例がなかつたの で有効率は逆に $87.5 \%$ (14/16，連絡杜絶 1) と僅かば かり高值に修正されることになつた．先述したごとく夫 々の有効判定基準は相互に無関係ではあるが，適当でな かつた判定基準を除外すると本法による有効率は 80 ～90 $\%$ の間に入り，3 年間以上の長期にわたる予後追跡が一 般の clinic については現実的と思われないので，多少 の低值で示される憾みはあるが処置を終つた時点から 6 カ月またはとれ以上の期間の再罹患阻止を以て有効と判 定する基準が最も妥当なものであると考光る.

乳酸菌移植後の経過観察中にその胵粘膜持続が岥われ た症例について（第 3 表）

17 例の series 中では 9 例が該当するが，ここでは後に 同様の処置を行い同様の経過をみている 2 症例を加えて 検討する。 そのうち 5 例に乳酸菌再移植を試みたが 1 例 (No. 9) は不成功, 2 例（Nos. 19，20）は再移植また は再々移植後に間もなく持続亦失, 他の 2 例 (No. 18,* K) は再移植成立後にすくなくともその持続岥失は確認 していない.この 5 症例は 1 例 (No. 18) を除きいら゙れ む閉経後の症例である.

乳酸菌持続の衰失と反復性尿路感染素因の復旧が相関

（註） * 51.7.19. 乳酸菌持続確認 ** 51.9.13. 乳酸菌持続聐失確認(校正時追加)
したとみられるのは 2 例 (Nos. 9，18）であるがそのう ちあとの 1 例は乳酸菌再移植が成立して再び尿路感染に 関する予後の観察に入つた。乳酸菌持続はなくなつたが その代りにある種のグラム陰性小桿菌が胵内細菌叢の predominant organism (以下 predominant org. と略記) となり，尿路感染症の反復罹患をみずに経過している者 が 5 例ある。そのらち在来の表㲹載のない series 以 外の症例について簡単に説明すると，その 1 例 (F) は 乳酸菌移植成立の後, 流産による Fluor 增加期間中の 医治によつて乳酸菌持続が失われたものと思われるが， そのまま経過を観察しているらちにグラム陰性小桿菌 （後出のコリネ（V)）が predominant になり以来 7 カ月間尿路感染を免れている。他の 1 例 $(\mathrm{K})$ は乳酸菌 移植を 2 回実施したが最終検査の時点で乳酸菌とグラム 陰性小桿菌の共存がみられ, 以来 8 力月間尿路感染を免 れている.この症例は閉経者で初回の乳酸菌移植による 持続が容易に喪われているので再移植は一応成立したが 現在では再び乳酸菌が襄われている公算が大きいと考兄 この項に追加した**. predominant のグラム陰性小桿菌 が Haemophilus parainfluenzae と同定された症例 (No. 11）ではとれが反復性尿路感染素因に与学影響は現在 のところ断定できない情況である. 残り 2 症例中の 1 例 （No. 19）はアンケートには応ずるが良好経過中なので 来院せず詳細不明, 最後の 1 例 (No. 12) は乳酸菌移植 成立後 8 カ月目に膀羘炎に罹患して来院した時点で乳酸 
第 3 表 乳酸菌持続を覀つた症例のその後の胵内細菌叢の predominant organisms と

反復性尿路感染阻止効果（11例）

\begin{tabular}{|c|c|c|c|c|c|c|c|c|}
\hline \multicolumn{3}{|c|}{ 症 例 } & \multicolumn{3}{|c|}{ 䐋粘膜の乳酸菌 } & \multirow{2}{*}{ 菌交代 } & \multirow{2}{*}{$\begin{array}{l}\text { 反復尿路感 } \\
\text { 染阻止効果 }\end{array}$} & \multirow{2}{*}{ 備 考 } \\
\hline Na & 名 & 生年 & 生 着 日 & 持続確認 & 喪失確認 & & & \\
\hline 9 & $\mathrm{~S}$ & 大 11 & 48. 1.30 & & 48. 3.20 & 不 定 & な し & $\begin{array}{l}\text { 再移植に成功 } \\
\text { せず }\end{array}$ \\
\hline 18 & $\mathrm{O}$ & 昭 3 & 1) 48.9 .13 & 50.2 .13 & 50.3 .30 & & $\begin{array}{l}\text { な し } \\
\text { (未定) }\end{array}$ & $\begin{array}{l}\text { 抗生物質使用 } \\
\text { による啡失か }\end{array}$ \\
\hline 19 & M & 昭 4 & 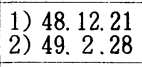 & & $\begin{array}{l}\text { 49. } 2.7 \\
49.3 .28 \\
\end{array}$ & & あり & \\
\hline 20 & $\mathrm{~T}$ & 昭 2 & $\begin{array}{l}\text { 1) } 49.1 .7 \\
\text { 2) } 49.5 .2 \\
\text { 3) } 50.10 .3\end{array}$ & $\begin{array}{l}49.3 .25 \\
49.8 .15 \\
50.12 .8\end{array}$ & $\begin{array}{l}\text { 49. } 4.15 \\
50.5 .12 \\
51.2 .16 \\
\end{array}$ & $\begin{array}{c}\mathrm{G}(\text { (一)小桿菌* } \\
(51.2 .16)\end{array}$ & あり & $\begin{array}{l}\alpha \text {-レンサ球菌 } \\
\text { 共存 } \\
\text { 臸 } \mathrm{pH} 5.6\end{array}$ \\
\hline 2 & $\mathrm{~S}$ & 昭 6 & 47. 5.16 & & 47. 7.26 & $\begin{array}{l}G(-) \text { 小桿菌 } \\
(49.5 .14)\end{array}$ & あり & \\
\hline 10 & $\mathrm{H}$ & 昭21 & 48.10. 2 & 49. 9.10 & 50.6 .27 & $\begin{array}{c}\mathrm{G}(\text {-1)桿菌* } \\
(49.6 .4)\end{array}$ & あり & $\begin{array}{l}\mathrm{G}(\text { (一)桿菌に } \\
\text { よる膀腅炎 }\end{array}$ \\
\hline \multirow[t]{3}{*}{13} & $\mathrm{~N}$ & 昭 6 & 48. 1.10 & 50.5 .6 & 50.10 .2 & $\begin{array}{l}\mathrm{G}(-) \text { 小桿菌 } \\
(50.10 .2)\end{array}$ & あり & \\
\hline & $\mathrm{F}$ & 昭11 & 49. 5.2 & & 50.3 .6 & $\begin{array}{c}\mathrm{G}(-) \text { 小桿菌* } \\
(50.8 .14)\end{array}$ & $\mathrm{c}: \stackrel{\text { あ }}{2 \times / 20 \text { 月 }}$ & $\begin{array}{l}\text { 移植前感染歴 } \\
C: 4 \times / 4 \text { 月 }\end{array}$ \\
\hline & $\mathrm{K}$ & 昭 7 & $\begin{array}{l}\text { 1) } 50.1 .4 \\
\text { 2) } 50.6 .16\end{array}$ & $\begin{array}{l}50.2 .3 \\
50.7 .7\end{array}$ & 50.3 .7 & $\begin{array}{l}\text { 乳酸菌之*** } \\
G(-1 \text { 小桿菌 } \\
\text { 共存す }\end{array}$ & $\begin{array}{c}\text { あ り } \\
\text { (感染なし) }\end{array}$ & $\begin{array}{l}\text { 移植前感染歴 } \\
\mathrm{C}: 3 \times / 1 \text { 年 }\end{array}$ \\
\hline 11 & $\mathrm{Y}$ & 昭10 & 48. 2.20 & & 49.11 .21 & $\begin{array}{c}\mathrm{G}(-) \text { 小桿菌** } \\
(50.6 .5)\end{array}$ & 未 定 & $\begin{array}{l}50.6 .5 . \text { 以後 } \\
\text { C: } 2 \times \\
\text { 窑pH } 5.0\end{array}$ \\
\hline 12 & $\mathrm{~S}$ & 昭 4 & 48. 1.6 & & 48. 8.1 & 少数の大腸菌 & あり & scanty \\
\hline
\end{tabular}

（註）*後出のコリネ(V) に相当. No. 20 のそれは“Haemophilus vaginalis”

** Haemophilus paraiufluenzae

*** 51.9.13. 乳酸菌消失, $G($ 一)小桿菌*のみとなる(校正時追加)

菌持続はなく, 更にそれから23力月目に膀胱炎に罹患し て来院したがいづれの際にも特定の細菌による胵内細菌 叢の predominancy はみられず，前年度の報告で反復性 尿路感染素因の復旧を予想したが，再々罹患後既に 9 カ 月間異常なく経過している. 最終来院時に胵粘膜にこ の症例に括ける在来からの尿路感染菌であつた大腸菌 OKO を保有していた。ただし本例は閉経者で腔内容お よびそれに含まれる有形成分が極めて寡少であつた（表 にはそれを scanty と表現して記載).

以上胵粘膜に乳酸菌持続が啔われた場合，それが自然 に起つていても或は抗生物質等の使用結果による（No. 18，F）ものであつても乳酸菌の再移植が可能であれば それを繰返すことによつて反復性尿路感染素因を抑えつ づけることが可能であると思われた。しかし概して閉経 女性に扣いては乳酸菌の移植乞のもの扣よび移植乳酸菌 の持続を維持することが困難であつた．他方乳酸菌生菌 の移植がそのあとで思わざる菌交代を継起させ，乳酸菌 持続が喂われたのちも反復性尿路感染素因の抑止に効果 を維持しらる可能性が示唆された。

\section{正常女性における胵粘膜細菌の動態について}

昭和 50 年 9 月中旬から 12 月中旬までの約 3 力月間に癌 検診の目的で当院婦人科外来を訪れた無作為の40例を対 象として検討した。その年齢分布は 30 歳台 $5 ， 40$ 歳台 25，50歳台 $9 ， 60$ 歳以上 1 である。

方法：癌細胞診のための vaginal pool 採取時に，別 に同じ材料を採取して鏡検扣よび培養検査にあてた。鏡 検はナマ標本について炎症細胞，上皮細胞，原虫などの 存否とその量を，染色標本はグラム染色を施したものに ついて細菌の種類とその過半数を占める細菌種を check し，培養検査は好気性培養と一部に嫌気性培養も行い， 主として乳酸菌, 腸内細菌, グラム陽性球菌叔よび coryneform bacteria をheck した。乳酸菌は先の報告に 用いたと同じく Briggs 寒天および BCP plate count agar を高層にし穿刺培養による方法をとつたが， coryneform bacteria 検出のためのチョコレート寒天平板塗抹ローソ ク法96時間培養における副所見やグラム染色，パパニコ ロー染色による鏡検所見も併せて判定した。腸内細菌は 一般の生化学的性状により, ブドウ球菌は coagulase 反応によつて Staphylococcus aureus と Staphylococcus epidermidis 飞（coagulase 反応を行わなかつた場合は 
第 4 表 正常女性の Vagiual pool 検查結果一覧表

\begin{tabular}{|c|c|c|c|c|c|c|c|c|c|c|}
\hline \multicolumn{4}{|c|}{ 対 } & \multicolumn{2}{|c|}{ 鏡 検 所 見 } & \multicolumn{2}{|c|}{ 培 養 所 見 } & \multirow{2}{*}{ 細胞診 } & \multirow{2}{*}{$\begin{array}{l}\text { predominant } \\
\text { orgauisms }\end{array}$} & \multirow{2}{*}{ 備 考 } \\
\hline Na & 年令 & 月経 & 尿感染 & ナマ標本 & 染色標本 & 好気性 & 嫌気性など & & & \\
\hline 1 & 45 & 閉 & $(-)$ & C. C (-) & $\begin{array}{l}G(V) \text { 小桿菌州 } \\
G(-) \text { 棹 } \\
G(\text { 菌+ } \\
\end{array}$ & $\begin{array}{l}\text { コリネ(V) } \\
\text { 乳酸菌 }\end{array}$ & \begin{tabular}{|l|} 
Propionibacterium \\
Klebsiella \\
Citrobacter \\
\end{tabular} & $\begin{array}{c}\text { Class I } \\
\text { 乳酸菌 }(+)\end{array}$ & コリネ(V) & 腔pH 4.6 \\
\hline 2 & 44 & 整 & $1 \times$ & C. C $(-)$ & $\mathrm{G}(+)$ 桿 菌卅 & 乳酸菌 & $\begin{array}{l}\text { St. epidermidis } \\
\text { Corynebacterium }\end{array}$ & $\begin{array}{c}\text { Class I } \\
\text { 乳酸菌 }(+)\end{array}$ & 乳酸菌 & 胵pH 4.0 \\
\hline 3 & 39 & 整 & $(-)$ & $\begin{array}{c}\text { C.C }(-) \\
\text { 白血球(+十) }\end{array}$ & $\mathrm{G}(+)$ 桿 菌卅 & 乳酸菌 & $\begin{array}{l}\text { Lactobacillus } \\
\text { St. epidermidis } \\
\text { Serratia }\end{array}$ & Class II & 乳酸菌 & 腔pH 4.2 \\
\hline 4 & 44 & 整 & $(-)$ & $\begin{array}{l}\text { C.C (+) } \\
\text { 白血球 (+t) }\end{array}$ & $\begin{array}{l}G(V) \text { 小桿菌册 } \\
G(+) \text { 棹 } \\
G(+) \text { 球 菌+ }\end{array}$ & $\begin{array}{l}\text { コリ齐(V) } \\
\text { 乳酸菌 }\end{array}$ & St. epidermidis & Class I & コリネ(V) & 膣pH 4.4 \\
\hline 5 & 50 & 不整 & $(-)$ & $\begin{array}{c}\text { トリコモナス(+) } \\
\text { 白血球(州) }\end{array}$ & $\begin{array}{l}G(V) \text { 桿 } \text { 菌+ } \\
G(+) \text { 球 菌+ }\end{array}$ & $\alpha$-レンサ球菌 & $\begin{array}{l}\text { Esch. coli } \\
\text { Klebsiella } \\
\alpha \text {-Streptococcus }\end{array}$ & $\begin{array}{c}\text { Class I } \\
\text { 炎症像 }(+)\end{array}$ & 䏽トリコモナス & 腔pH 5.6 \\
\hline 6 & 50 & 整 & $(-)$ & $\begin{array}{l}\text { C. C }(+) \\
\text { 白血球 }(+)\end{array}$ & $\begin{array}{l}G(V) \text { 桿 菌卅 } \\
G(一) \text { 小桿菌+ }\end{array}$ & 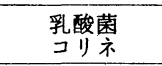 & St. epidermidis & $\begin{array}{c}\text { Class I } \\
\text { 乳酸菌 }(+)\end{array}$ & 乳酸菌 & 腔pH 4.0 \\
\hline 7 & 62 & 閉 & $(-)$ & scanty & $G(+)$ 球 菌十 & $\begin{array}{l}\text { 白ブドウ球菌 } \\
\text { クレプシエラ }\end{array}$ & $\begin{array}{l}\text { St. epidermidis } \\
\text { Klebsiella } \\
\text { Cit robacter }\end{array}$ & Class I & $(-)$ & $\begin{array}{l}\text { (腔pH 7.0) } \\
\text { MRによる }\end{array}$ \\
\hline 8 & 38 & 整 & $(-)$ & $\begin{array}{c}\text { C.C }(-) \\
\text { 白血球 }(+)\end{array}$ & $\begin{array}{l}\mathrm{G}(\mathrm{V}) \text { 小桿菌畠+ } \\
\mathrm{G}(+) \text { 棹 } \\
\mathrm{G}(+) \text { 球 菌+ }\end{array}$ & $\begin{array}{l}\text { コリネ(V) } \\
\text { 乳酸菌 }\end{array}$ & $\begin{array}{l}\text { Corynebacterium } \\
\text { St. epidermidis }\end{array}$ & Class I & コリネ(V) & 腟pH 4.2 \\
\hline 9 & 44 & 不整 & $(-)$ & C. C $(-)$ & $\begin{array}{l}\mathrm{G}(+) \text { 桿 菌册 } \\
(2 \text { 種類 })\end{array}$ & $\begin{array}{c}\text { 乳酸菌 } \\
\text { 白ブドウ球菌 }\end{array}$ & $\begin{array}{l}\text { Enterobacter } \\
\text { cloacae } \\
\text { Klebsiella }\end{array}$ & Class I & 乳酸菌 & 腟pH 4.8 \\
\hline 10 & 40 & 整 & $(-)$ & $\begin{array}{c}\text { C. C }(-) \\
\text { 白血球 }(+ \text { H) }\end{array}$ & $\begin{array}{l}\mathrm{G}(+) \text { 棹 } \text { 菌卅 } \\
(2 \text { 種類) } \\
\mathrm{G}(-) \text { 桿 菌+ }\end{array}$ & 乳酸菌 & $\begin{array}{l}\text { St. epidermidis } \\
\text { Esch. coli }\end{array}$ & Class I & 乳酸菌 & 腔pH 4.0 \\
\hline 11 & 48 & 整 & $(-)$ & $\begin{array}{l}\text { C. C ( }(+) \\
\text { 白血球(\#) }\end{array}$ & G(V)桿 菌卅 & 乳酸菌 & & Class I & 乳酸菌 & 腟pH 4.2 \\
\hline 12 & 50 & 不整 & $(-)$ & scanty & $\mathrm{G}(+)$ 桿 菌+ & レンサ球菌 & & Class I & $(-)$ & 腔pH 4.8 \\
\hline 13 & 42 & $(-)$ & $2 \times$ & scanty & 陰 性 & 大腸菌 & \begin{tabular}{|l|} 
Esch. coli \\
Enterococcus \\
\end{tabular} & Class I & $(-)$ & 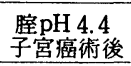 \\
\hline 14 & 53 & 閉 & $(-)$ & C. $\mathrm{C}(+)$ & $\mathrm{G}(+)$ 桿 菌册 & 乳酸菌 & St. epidermidis & Class I & 乳酸菌 & 腔pH 4.0 \\
\hline 15 & 47 & 閉 & $(-)$ & $\begin{array}{c}\text { C. C (+) } \\
\text { 白血球 }(+)\end{array}$ & $\begin{array}{l}\mathrm{G}(\mathrm{V}) \text { 小桿菌册 } \\
\mathrm{G}(+) \text { 桿 菌事 }\end{array}$ & $\begin{array}{l}\text { 乳酸菌 } \\
\text { Candida }\end{array}$ & $\begin{array}{l}\text { Corynebacterium } \\
\text { Enterococcus } \\
\text { St. epidermidis } \\
\end{array}$ & Class I & 乳酸菌 & 腟pH 4.2 \\
\hline 16 & 47 & 整 & $1 \times$ & C. C $(-)$ & $\begin{array}{l}G(+) \text { 桿 菌卅 } \\
G(+) \text { 球 菌+ }\end{array}$ & 乳酸菌 & \begin{tabular}{|l|} 
Klebsiella \\
Enterococcus \\
$\alpha$-Streptococcus \\
\end{tabular} & $\begin{array}{c}\text { Class I } \\
\text { 乳酸菌 }(+)\end{array}$ & 乳酸菌 & 腔 $\mathrm{pH} 4.0$ \\
\hline 17 & 44 & 整 & $(+)$ & $\begin{array}{c}\text { C. } C(+) \\
\text { Candida }(+)\end{array}$ & $\begin{array}{l}\text { G(V)小桿菌册 } \\
\text { Candida }\end{array}$ & $\begin{array}{c}\text { コリネ(V) } \\
\text { Candida } \\
\text { 白ブドウ球菌 }\end{array}$ & \begin{tabular}{|l} 
Klebsiella \\
Enterococcus \\
\end{tabular} & Class I & コリネ(V) & 腔 $\mathrm{pH} 4.0$ \\
\hline 18 & 32 & 整 & $(-)$ & $\begin{array}{c}C . C( \pm) \\
\text { 白血球 }(+)\end{array}$ & $\begin{array}{l}\mathrm{G}(-) \text { 小桿菌州 } \\
\mathrm{G}(+) \text { 球 菌十 }\end{array}$ & $\begin{array}{l}\text { コリネ(V) } \\
\text { 乳酸菌 }\end{array}$ & $\begin{array}{l}\text { St. epidermidis } \\
r \cdot \text { Streptococcus } \\
\end{array}$ & Class I & コリネ(V) & $\begin{array}{l}\text { 脜pH } 4.4 \\
\text { 血球汇コ } \\
\text { リネ着 }\end{array}$ \\
\hline 19 & 32 & 整 & $2 \times$ & C. C (WH) & $\begin{array}{l}\mathrm{G}(-) \text { 小桿菌册 } \\
\mathrm{G}(-) \text { 楿 囷+ }\end{array}$ & $\begin{array}{l}\text { コリネ }(\mathrm{V}) \\
\text { 白ブドウ球菌 } \\
\text { レンサ球菌 }\end{array}$ & $\begin{array}{l}\text { Esch. coli } \\
\text { Enterococcus }\end{array}$ & Class I & コリネ(V) & 腔 $\mathrm{pH} 4.6$ \\
\hline 20 & 40 & $(-)$ & $(-)$ & scanty & 陰 性 & 陰 性 & & Class I & $(-)$ & 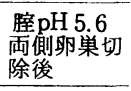 \\
\hline 21 & 45 & 閉 & $(-)$ & scanty & 陰 性 & ブドウ球菌 & & Class I & $(-)$ & 腔pH 5.6 \\
\hline 22 & 53 & 閉 & $(-)$ & scanty & 陰 性 & 陰 性 & & Class I & $(-)$ & 腔pH 5.6 \\
\hline 23 & 50 & 閉 & $(-)$ & C. C $(-)$ & $\begin{array}{ll}\mathrm{G}(-) & \text { 棹 } \\
\mathrm{G}(-) & \text { 菌菌+ }\end{array}$ & 白ブドウ球菌 & & Class I & $(-)$ & 腟pH 5.6 \\
\hline
\end{tabular}




\begin{tabular}{|c|c|c|c|c|c|c|c|c|c|c|}
\hline \multicolumn{4}{|c|}{ 対 } & \multicolumn{2}{|c|}{ 鏡 検 所 見 } & \multicolumn{2}{|c|}{ 培 養 所 見 } & \multirow{2}{*}{ 細胞診 } & \multirow{2}{*}{$\begin{array}{l}\text { predominant } \\
\text { organisms }\end{array}$} & \multirow{2}{*}{ 備 考 } \\
\hline $\mathrm{Na}$ & 年令 & 月経 & 尿感染 & ナマ標本 & 染色標本 & 好気 性 & 嫌気性など & & & \\
\hline 24 & 45 & $(-)$ & $(-)$ & C. C (t) & $\begin{array}{l}\mathrm{G}(\text { (一)小桿菌+1 } \\
\mathrm{G}(+) \text { 桿 菌+ }\end{array}$ & $\begin{array}{l}\text { コリネ(V) } \\
\text { 乳酸菌 }\end{array}$ & & Class I & コリネ(V) & 膣pH 4.8 \\
\hline 25 & 38 & 整 & $(-)$ & C. C $(-)$ & $\mathrm{G}(\mathrm{V})$ 桿 菌卅 & $\begin{array}{c}\text { 乳酸菌 } \\
\text { 白ブト菌 }\end{array}$ & $\begin{array}{l}\text { St. epidermidis } \\
\beta \text {-Streptococcus }\end{array}$ & Class I & 乳酸菌 & 腔pH 4.0 \\
\hline 26 & 45 & 整 & $(-)$ & C. C $(-)$ & 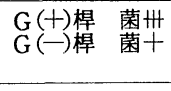 & $\begin{array}{l}\text { レンサ球菌 } \\
\text { 白ブドウ球囷 }\end{array}$ & $\begin{array}{l}\text { Enterococcus } \\
\text { St. epidermidis }\end{array}$ & $\begin{array}{c}\text { Class I } \\
\text { 乳酸菌 }(+)\end{array}$ & 乳酸菌 & 腟pH 4.2 \\
\hline 27 & 50 & 閉 & $(-)$ & scanty & $\mathrm{G}(-)$ 桿 菌十 & $\begin{array}{c}\text { 大腸菌 } \\
r \text {-レンサ球菌 }\end{array}$ & Esch. coli & Class I & $(-)$ & 腟pH 4.8 \\
\hline 28 & 43 & 整 & $(-)$ & $\begin{array}{c}\text { C. C (+) } \\
\text { 白血球 }(+)\end{array}$ & $\begin{array}{ll}\mathrm{G}(\mathrm{V}) \text { 桿 } & \text { 菌卅 } \\
\mathrm{G}(-) \text { 球 } & \text { 菌+ }\end{array}$ & $\begin{array}{c}\text { 白ブドウ球菌 } \\
\text { Candida }\end{array}$ & $\begin{array}{l}\text { St. epidermidis } \\
\text { Enterococcus }\end{array}$ & $\begin{array}{c}\text { Class I } \\
\text { 乳酸菌 }(+)\end{array}$ & 乳酸菌 & 腔pH 5.0 \\
\hline 29 & 49 & 閉 & & C. C (+) & $\mathrm{G}(\mathrm{V})$ 小桿菌卅 & $\begin{array}{c}\text { コリネ(V) } \\
\text { レ゙サ球菌 } \\
\text { 白ブドウ球菌 }\end{array}$ & $\begin{array}{l}\text { Corynebacterium } \\
\text { Enterococcus } \\
\text { St. epidermidis }\end{array}$ & Class I & コリネ (V) & 腔pH 4.8 \\
\hline 30 & 49 & 閉 & $(-)$ & C. $\mathrm{C}(-$ & $\begin{array}{l}G(V) \text { 小桿菌卅 } \\
G(+) \text { 球 菌 }\end{array}$ & $\begin{array}{l}\text { コリ夜(V) } \\
\text { 大腸囷 }\end{array}$ & $\begin{array}{l}\text { Klebsiella } \\
\text { Esch. coli } \\
\alpha \text {-St reptococcus }\end{array}$ & Class I & コリネ(V) & 臸pH 5.2 \\
\hline 31 & 47 & 閉 & $(-)$ & C & $\begin{array}{l}G(+) \text { 小桿菌册 } \\
G(+) \text { 桿 } \\
\text { 囷事 }\end{array}$ & $\begin{array}{c}\text { コリネ(V) } \\
\text { 乳酸菌 } \\
\alpha \text {-レンサ球菌 }\end{array}$ & $\begin{array}{l}\text { Lactobacillus } \\
\text { Enterococcus } \\
\alpha \text {-St reptococcus }\end{array}$ & Class I & コリネ(V) & 腔pH 5.2 \\
\hline 32 & 44 & 不整 & $(-)$ & C. C $(-)$ & $\mathrm{G}(+)$ 桿 菌州 & $\begin{array}{l}\text { コリネ(V) } \\
\text { 乳酸菌 }\end{array}$ & $\begin{array}{l}\text { Corynebacterium } \\
\text { St. epidermidis } \\
\alpha \text {-St reptococcus }\end{array}$ & $\begin{array}{c}\text { Class I } \\
\text { 炎症像 }(+)\end{array}$ & コリネ(V) & 腔pH 5.6 \\
\hline 33 & 40 & 整 & $(-)$ & C. C $(-)$ & $\mathrm{G}(\mathrm{V})$ 桿 菌卅 & $\begin{array}{l}\text { 乳酸菌 } \\
\text { Candida }\end{array}$ & $\begin{array}{l}\text { Esch. coli } \\
\text { Enterococcus } \\
\text { Candida }\end{array}$ & Class I & 乳酸菌 & 腔 $\mathrm{pH} 4.0$ \\
\hline 34 & 42 & 整 & $(-)$ & $\begin{array}{c}C . C(+) \\
\text { 白血球 }(+)\end{array}$ & 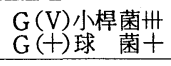 & コリネ(V) & & $\begin{array}{c}\text { Class II } \\
\text { 炎症像 }(+) \\
\end{array}$ & コリネ(V) & 腔pH 4.8 \\
\hline 35 & 44 & $(-)$ & $(-)$ & C. $C(+)$. & $G(+)$ 桿 菌州 & $\begin{array}{l}\text { 乳酸菌 } \\
コ リ ネ(V)\end{array}$ & & $\begin{array}{c}\text { Class I } \\
\text { 乳酸菌 }(+) \\
\end{array}$ & 乳酸菌 & $\begin{array}{l}\text { 腟pH } 4.0 \\
\text { 子宮癌術後 }\end{array}$ \\
\hline 36 & 49 & 整 & $(-)$ & $\begin{array}{c}\text { C. } C(+) \\
\text { 白血球 }(+)\end{array}$ & $\begin{array}{l}\mathrm{G}(+) \text { 棹 菌曲 } \\
\mathrm{G}(\text { 小)桿菌事 }\end{array}$ & $\begin{array}{l}\text { 乳酸菌 } \\
\text { Candida }\end{array}$ & St. epidermidis & $\begin{array}{c}\text { Class II } \\
\text { 炎症像 }(+)\end{array}$ & 乳酸菌 & 腔pH 4.0 \\
\hline 37 & 43 & 整 & $(-)$ & C. $C(+)$ & $\begin{array}{l}G(-) \text { 小桿菌+ } \\
G(+) \text { 球 囷+ }\end{array}$ & $\begin{array}{l}\alpha \text {-レンサ球菌 } \\
\text { 白ブドウ球菌 }\end{array}$ & $\begin{array}{l}\alpha \text {-St reptococcus } \\
\text { St. epidermidis }\end{array}$ & Class I & $(-)$ & $\begin{array}{l}\text { (腔pH 7.0) } \\
\text { MRによる }\end{array}$ \\
\hline 38 & 48 & 整 & $(-)$ & $\begin{array}{c}\text { C. C (+) } \\
\text { 白血球 }(+)\end{array}$ & $\begin{array}{l}\mathrm{G}(\mathrm{V}) \text { 小桿菌册 } \\
\mathrm{G}(+) \text { 桿 囷+ }\end{array}$ & $\begin{array}{l}\text { コリネ(V) } \\
\text { 乳酸菌 }\end{array}$ & Corynebacterium & Class I & コリネ(V) & 腔 $\mathrm{pH} 4.2$ \\
\hline 39 & 50 & 閉 & $(-)$ & scanty & $G(V)$ 球 菌 + & $\alpha$-レンサ球菌 & $\begin{array}{l}\alpha \text {-Streptococcus } \\
\text { St. epidermidis } \\
\text { St. aureus }\end{array}$ & Class I & $(-)$ & $\begin{array}{l}\text { (臆pH 7.0) } \\
\text { MRによる }\end{array}$ \\
\hline 40 & 51 & 不整 & $1 \times$ & scanty & $\mathrm{G}(+)$ 球 菌十 & $\begin{array}{c}\text { レンサ球菌 } \\
(\alpha お よ ひ ゙ ~ \\
(\alpha)\end{array}$ & St. epidermidis & Class II & $(-)$ & \\
\hline
\end{tabular}

96時間培養集落の色彩から白色ブドウ球菌と表現), レ ンサ球菌は SF 培地に生育するものを腸球菌, 他の heterogenous の菌種は $10 \%$ ウマ血寒上での溶血性によつて $\alpha, \beta$, および $\gamma$ レンサ球菌とし， $\beta$ 溶血を示すものはバ シトラシンテストによつてA型か否かを確認した。嫌気 性菌については材料を直接 GAM 半流動高層寒天に接 種して輸送用とし，4 時間以内に塗抹分離し steel wool 法によつて培養した。

その他 paper 法による胵 $\mathrm{pH}$ の測定, 問診による最 近 6 カ月間の尿路感染症前歴の有無および卵巣機能の情 況を月経発来の現況から整, 不整, および閉経の語で表 現した。
結果の判定とその記載（第 4 表）：胵内容中の微生物 については predominant org. と commensals とを書き 分けた. predominant org. の判定にはその存在情況の他 に機能面をる考慮にいれた，即ち宿主との関聠に打い て，また同じ環境内に棲息する他の微生物との関聠に扤 いてそれがある程度の生物学的影響を行使しうる情況に あることが必要であると考皃た，具体的には被検材料が 豊富であることとそれが細胞成分扣よび細菌成分を多量 に含んでいるときにある微生物がそこに存在する微生物 構成員の過半数を占めている場合にそれを predominant であるとし，もし被検材料が量的に，あるいは含まれる 有形成分が寡少である場合（被検材料のかかる情況は 
scanty と表現した）には宿主との関聠においてその微 生物の存在には殆んど生物学的意義がないものと考光, 仮令ある微生物がそこに単独で存在する場合でもそれを predominant org. とはしなかつた. 従つて例兄ば Trichomonas 胵炎を反復している症例では腔内容中に数的 にはより多数の微生物が存在していても Trichomonas

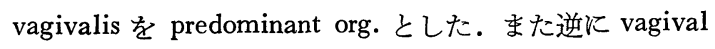
pool 採取の時点で病原的役割りを示さずに可成り多数 存在した Candida などは commensals の1つと考光 た.

鏡検による predominant org. が必ずしもすべて培養 可能であるとは限らなかつたが，それはむしろcommensals についてより著しかつたと考觉られる．従つて培養 検查の結果は predominant org. などの判定には従的に 利用した。鏡検による微生物の標示は Trichomonas と 真菌を除きグラム陽性, 陰性あるいは variable（夫々 $\mathrm{G}(+), \mathrm{G}(-), \mathrm{G}(\mathrm{V})$ の略語で表に記載) の球菌また は桿菌などとした。 そして predominant org. に相応す るものは冊で示したが, 若し 2 種類の organisms が鏡 検所見でともに卅，あるい性およびサで示される場合 には仮に培養陽性のものを predominant org. とした。

一般に培養検查の結果を鏡検所見に照合すると，概ね グラム陽性（時に陰性〜 variable）の球菌はブドウ球菌 とレンサ球菌に，グラム陽性（時に陰性〜variable）の 桿菌は乳酸菌に，同じくグラム陰性（時に variable〜陽 性) の小桿菌は coryneform bacteria に, そしてグラ ム陰性桿菌は略々腸内細菌に相応した。 その他上述の coryneform bacteria については培養集落上飞 $\mathrm{H}_{2} \mathrm{O}_{2}$ 液 を滴下して catalase の有無を検し, catalase 陰性のも のは特に“コリネ (V)”と標記した． catalese 反応陽 性のものは単に“コリネ”と標記鏡検所見が陽性でも培 養集落の兄られなかつたものも同じ取扱いをした。ま た表の培養所見欄のらち “嫌気性菌など”の項は順天堂 大学病院中央検査部からの報告をそのまま記載した。 胵の $\mathrm{pH}$ の測定は東洋滤紙製の $\mathrm{pH}$ 試験紙によつた. BCG (Brom cresol green, 測定可能域 $\mathrm{pH} 3.6 \sim 6.0$ ) MR (Methyl red, 測定可能域 $\mathrm{pH}$ 5.0 7.4) を併用乙 てみたが，夫々による $\mathrm{pH}$ 標示は両者に共通の $\mathrm{pH}$ 領 域でも一致をみないのが常であつた。他方全例を通じて BCG 試験紙による測定不能域にある者 3 例に対して $\mathrm{MR}$ 試験紙によるそれは15例に及んだので，夫々の示す $\mathrm{pH}$ の二重標記をさけるためもあつてすべての $\mathrm{pH}$ 標示は BCG 試験紙による価に統一することとした。
第 1 図 腟内細菌叢の predominant organisms と胵 $\mathrm{pH}$

$\mathrm{pH}$

$\begin{array}{llllllllll}4.0 & 4.2 & 4.4 & 4.6 & 4.8 & 5.0 & 5.2 & 5.4 & 5.6 & 6.0\end{array}$

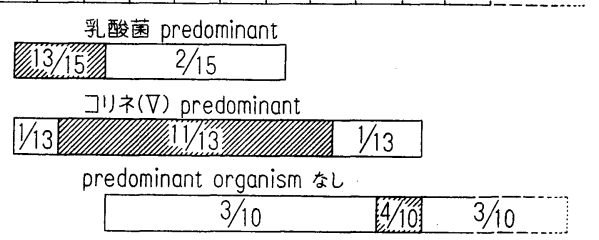

pH値は東洋沪紙pH試験紙B.C.G.(括弧内はM.R.)による

第 2 図卵宩機能の有無と腔内細菌叢の predominant organisms

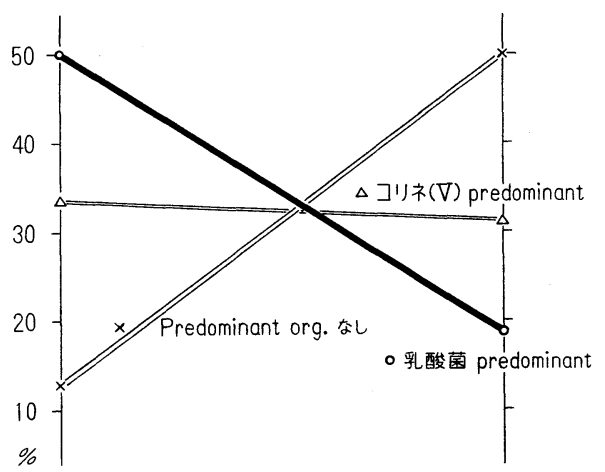

あり：24例——畈㫦機能—— なし：16例

その他ナマ標本では Gardner \& Dukes（1955）の云 5 “clue cells”（表には c.c. と略記, 第 3 図) の検討 も行つた。な和細胞診の成績では異型細胞を有した例は なく, 36例が class I と判定され, 細菌学的に被検材料 のすべてが比較的に清浄であることが予想された。

結果：以上の方法によつて predominant org. として checkされたものは僅かに乳酸菌, ある種の coryneform bacteria（コリネ（V））和よび病的状況を起させてい た Trichomonas vagiualis にすぎなかつた。そして predominant org. を欠く情況が11例にみられた。 その11例の 卵巣機能に基く内訳は月経整 1 , 不整 2 , 閉経 8 であつ た。

つぎに第 4 表の成績にもとづく $2 \sim 3$ の検索結果につ いて述べる。

1. predominant org. と胵 $\mathrm{pH}$

a . predominant org. を欠く11例について

“scanty material” の 9 例を含む. 鏡検培養ともに細 菌陰性の者 2 例あり, 卵巣剔除後拉よび閉経例で臸 $\mathrm{pH}$ 
第 3 図“clue cell”（ナマ標本，油漫）

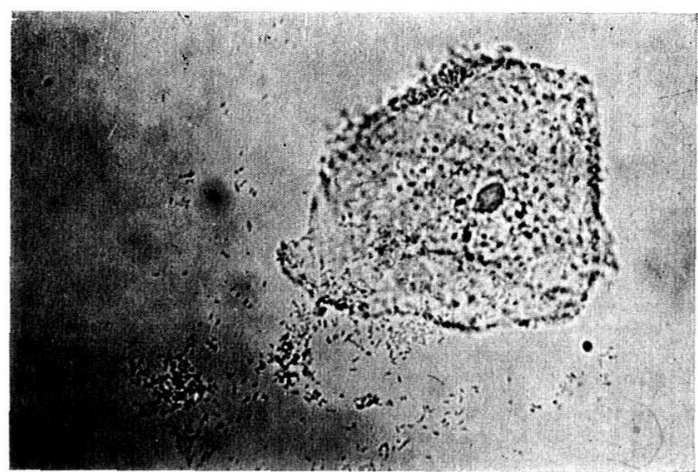

第 5 図コリネ（V) 培養菌, グラム染色

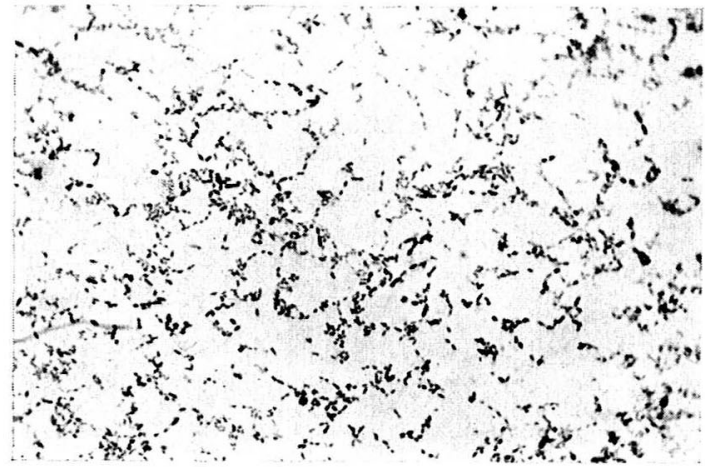

第 7 図急性䧛胱炎尿中のコリネ (V), その 1

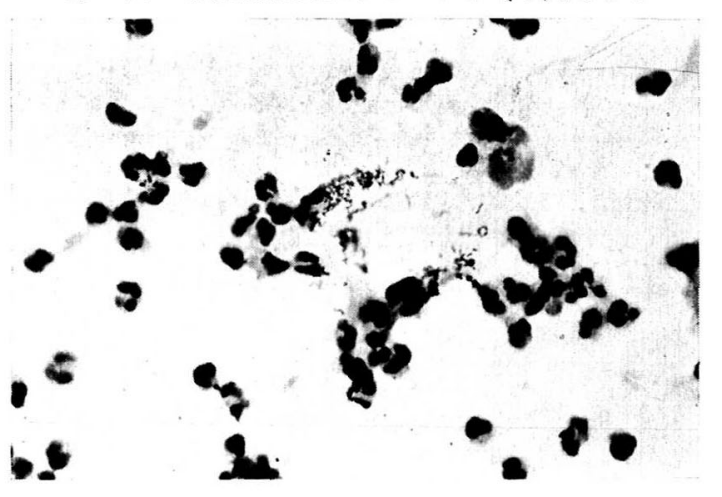

第 4 図 同左（ユリセル染色）

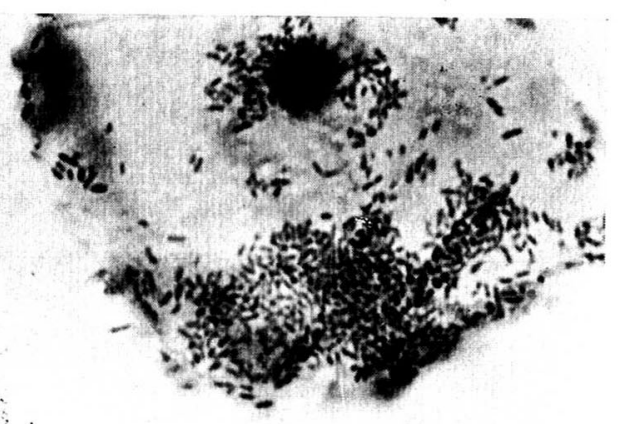

第 6 図正常胵分泌物中で白血球細胞之密接な関係 をもつて存在するコリネ（V),グラム染色

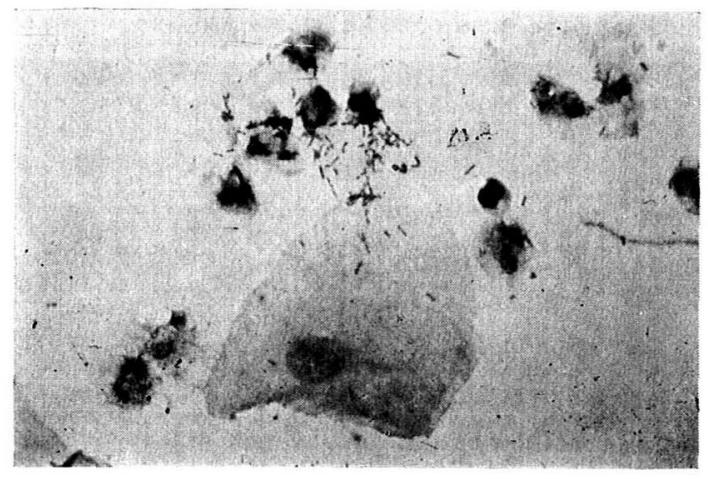

第8図急性膀脱炎灰中のコリネ $(\mathrm{V})$, その 2

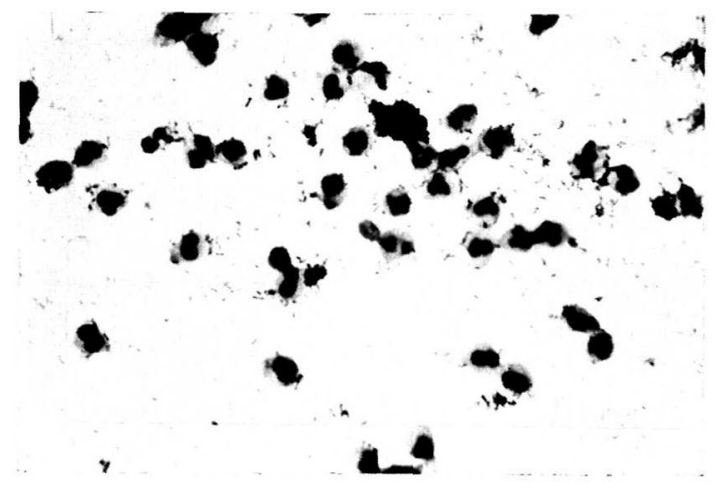


はいづれも5.6.この情況を基準として僅かながら存在 した細菌種と腟 $\mathrm{pH}$ の関係をみると，Staphylococcus epidermidis などグラム陽性球菌の存在する 2 例はいら゙ れも $\mathrm{pH} 5.6$ ，グラム陽性桿菌（乳酸菌がリネのいづ れかと思われた）の存する 1 例お占び大腸菌と腸球菌が 存在する 1 例では夫々 4.4 と 4.8, Klebsiella と Citroba cter が共存する 1 例と $\alpha$ レンサ球菌などが存在する 2 例 では6.0であつた。

小括 : 閉経後胵内容夏少で略々無菌状態での腔 $\mathrm{pH}$ は

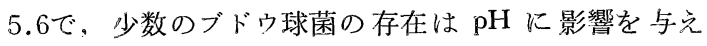
ず，グラム陽性桿菌と腸内細菌のあるものは酸性化傾向 を， $\alpha$ レンサ球菌と腸内細菌のあるものはアルカ!化傾 向を与えることが示唆された。

b。乳酸菌が predominant org。であつた15例につい $\tau$

純粋に乳酸菌だけしか存在しなからた例はなかつだ。 腟 $\mathrm{pH}$ 亿影響を与えないに思われる Staphylococcus

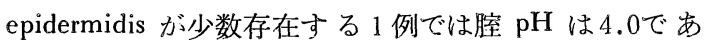
つた。コリネ共存の 2 例とコリネおよび Staphylococcus epidermidis が共存する 3 例については $\mathrm{pH}$ 4.0 4.2 で, 乳酸菌のもたらす $\mathrm{pH}$ を4.0と考光ればコリネの 共存は乳酸菌による腟 $\mathrm{pH}$ に影響を与えないと思われ た。 大腸菌乃至は腸球菌などの腸内細菌の共存する者 5 例あり，中にはコリネや Staphylococcus epidermidis を 共存する例を含むがそれらは前項の知見から乳酸菌のる たらす胵 $\mathrm{pH}$ に影響を与えないものとして一括した。

この 5 例での胵 $\mathrm{pH}$ は4.0 5.0で, $\mathrm{pH} 5.0$ を示した 例は Candida が共存していた。ただしこの5 例の中に Candida の共存する者 3 例あり，他の 2 例での $\mathrm{pH}$ は乳 酸菌のもたらすそれに一致していたので Candida が胵 $\mathrm{pH}$ をアルカ側に偏移させるか否か不詳である。残り の 4 例について Enterobacter cloacae が共存する例 で $\mathrm{pH} 4.8$ ，他の 3 例は夫々 Serratia 等, $\beta$ レンサ球菌

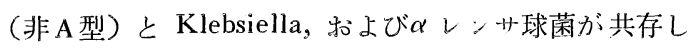
たが腟の $\mathrm{pH}$ は4.0〜4.2であつた。

小括: 乳酸菌が predominant org。である場合の腔 $\mathrm{pH}$ は4.0〜4.2で, ブドウ球菌, コリネ, 大腸菌, 腸球菌,

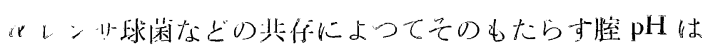
影響をらけにくい。ただ共存する organismsによつては 多少アルカリ側に偏移さ机る可能性も西るがその範囲は せいぜい5.0までであろう。

c。コリネ（V)が predominant org。であつた13例 について
乳酸菌が commensal として少数〜中等数に存する者 8 例あり，そのうち乳酸菌の久共存する 2 例の胵 $\mathrm{pH}$ は 4.2 と 4.8 , 乳酸菌と少数の Staphylococcus epidermidis が共存する 2 例では 4.2 と 4.4 , 乳酸菌とレンサ球菌が共 存する 3 例では4.4 5.6であつた。乳酸菌が共存しない 者は 5 例で, そのうち少数のグラム陽性球菌のみ共存す る 1 例の腔 $\mathrm{pH}$ は 4.8 , 他の 4 例は夫々大腸菌, Klebsiella, 腸球菌, $\alpha$ レンサ球菌が共存して $\mathrm{pH}$ は4.0 5.20 範囲内にあつた. 5.0 以上の $\mathrm{pH}$ 值を示す例には 乳酸菌の有無に不拘 $\alpha$ レン性球菌が共存していた。

小括：コリネ（V）が predominant org. である場合 には過半数が乳酸菌を commensal として共存させてい た。少数のグラム陽性球菌の久共存した例での腔 $\mathrm{pH}$ が コリネ（V)によつてもたらされる臸 $\mathrm{pH}$ に近い上思 われ、その值は4.8付近であのた。これは無菌状態の胵

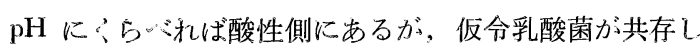
ていてもその $\mathrm{pH}$ 領域は4.2〜 $4.8 て ゙$ 乳酸菌がもたらす $\mathrm{pH}$ よりはアルカリ側にあつた。 $\alpha$ レン开球菌の共存は 胵 $\mathrm{pH}$ をアルカリ側に偏移させることが示唆された。

d. Trichomonas vaginalis が predominant org. であ るとみとめられたのは1例で, その腟 $\mathrm{pH}$ は5.6。病的 状態なのでその標示は意味がないと思われる。この $\mathrm{pH}$ が Trichomonas によつてもたらされた独自のものであ るのか，または共存したコリネや る相加的効果によるものであるのかは不詳.

以上の結果を綜合すると一般的には, 乳酸菌が predominant である場合の腟 $\mathrm{pH}$ は4.0 - 4.2, コリネ (V) が predominant である場合は 4.2 5.2, predominant org。を欠く場合は5.6となり, 乳酸菌 predominant の際 にはそ固有の $\mathrm{pH}$ 域が共存する commensals 沈よ て偏移させら机ることはすくないが、コリネ(V) pre dominant の際または predominant org。を欠く場合には 共存するまたは偶々存在する微生物の種類によっては俼 $\mathrm{pH}$ 域が左右に拡大されると云らことができる。

この series の観察では腸内細菌の共存が胵 $\mathrm{pH}$ に及 ぼす影響は明確にしえなかつたが，すくなくともれレン サ球菌の共存は明らかに腔 $\mathrm{pH}$ をつルカリ側に偏移せ しめる傾问が示さ扎た（第1図）。

2. predominant org. $\succeq し て の$ coryneform bacteria について

Corynebacterium に類似の菌形態並びに排列を示す細 菌種が多々存在するのでこの論文では敢えて coryneform bacteria の語を用いたが，害は所謂 diphtheroids 上略ふ 
同義のものである．腟内容の鏡検または培養で corynaform bacteria が存在したのは22例で, 別に乳酸菌か リネか判別できなかつた 1 例（培養ではいら゙れの細菌種 も觉られなかた）がある。これらのらち鏡検所見のみ 陽性で培養集落の兄られなからた者 7 例，培養集落が壳 られた者15例でそのらち1例だけが集落の catalase 反 応陽性 : 真正の Corynebacterium : であつた. catalase 反応陰性のものはコリネ (V) と標記 し他はすべてコ リネとしたが，この意味でのコリネ 8 株の所在は乳酸 菌 predominant の情況に共存したもの 6 , Trichomonas vaginalis predominant 共存したもの 1 , predominant org. を欠く情況でグラム陽性球菌と共存したもの 1 で, いら゙れるとれ自体が predominant org. としてあつた例 はなかつた。それに反してコリネ（V)は 1 株が乳酸菌 predominant の情況に共存した以外はすべて predominant org. として存在していた。 その13例に拈ける胵の $\mathrm{pH}$ 領域は前項でのべたごとく4.2 5.2で, predominant org. を欠く情況での腟 $\mathrm{pH}$ よりも酸性側にあり, 乳酸 菌には及ばぬまでもコリネ（V) は明らかに胵粘膜に拉 ける “acid producer”之考穴てよい存在である. 本菌 は主としてグラム陰性の Corynebacterium とも Haemophilus ともとれる形態と排列を示して上皮細胞上に集 まつて存在する小桿菌（第 4 図）で, グラム染色性は標 本全体の厚薄と細菌の蝟集する度合いによつて異るがむ しろグラム variable と表現するのが適当のようである. 通常の血液寒天やチョコレート寒天平板上での発育は不 良で, ローソク法96時間の培養でも径 $0.5 \mathrm{~mm}$ に及ぶ 集落はえられなかつた。集落は透明円形湿潤で容易に emulsify される. 集落形成が明膫でない場合でも streak 上の材料を鏡検すると上皮細胞体に一致して蝟集する菌 塊の一部が上皮細胞体外飞這いだして恰かも培養基上で の発育をはじめたばかりと思わせる情況をみることが屡 々であつた。 その集落には Haemophilus に特有とされ る satellism をみることがなく，吾々の用いた10\%ウマ 血液を素材とする培地上での溶血（ $\alpha$ type）を示したの は1株にすぎなかつた。培養菌は殆どがグラム陰性に染 色され, 柵状, $\mathrm{V}$ 字状, 分枝状などの排列を示し, 菌体 は一端棍棒状膨大を示し, 或はグラム陽性顆粒を蔵する など多様であつたが filament 形成はみられなかつた (第 5 図).なおコリネ（V) は僅か 1 例（No. 18）飞拉 いてではあるが白血球と密接な位置的関係を以て胵分泌 物中に存在するのが観察され (第 6 図), それが炎症性反 応, 換言すれば病原的役割りを荷いらるものであること
が示唆された。

コリネ（V)についてここに述べたような細菌学的特 徵を有するもので在来 check されているものに“Haemophilus vaginalis”之呼ばれる細菌がある ${ }^{13)}$. その正 確な分類学的位置づけのための研究をすすめている Lapage はかつて既知の Haemophilus spp. を含む保存 17 株と臨床分離37株の小桿菌について, グラム染色性, 細 菌形態, 培養集落形態と satellism の有無, catalase 反 応, oxydase 反応, nitrit 形成その他の検査を行つて 検討した ${ }^{16)}$ 。その結果によると彼が “possible Haemophilus vaginalis”とした22株の細菌株は彼が実施した 検查項目を吾々がコリネ（V）について可能であつた catalase 反応陰性所見の段階までに限定して比較してみ ると，その限りの条件を充す類似細菌の $80 \%$ を占めてい る.この事実から吾々がコリネ（V）と標記した細菌が 所謂 “Haemophilus vaginalis”である可能性も略々80 \%であると推測することができる。な掊養集落の兄ら れなかつた coryneform bacteria（コリネの 7 株）につ いても，その理由が吾々の用いた通常の培地に集落を形 成するに足るだけの heavy inocula が被検材料中に含 まれていなかつたからであると解すると（何故ならこれ らコリネはすべてが predominant org. としては存在し ていなかつたから), それらの中にも“Haemophilus vaginalis”が高率に含まれる可能性がある.

3. 卵巣の機能情況と 腔内容中の predominant org. について

卵巣の機能情況は問診による月経発来の模様から整， 不整, 閉経後拉よび卵巣剔除症例に分け, 夫々の情況に ついて predominant org. をしらべてみるとつぎのごと くであつた。

月経整19例：乳酸菌 predominant $11, コ リ ネ(V)$ predominant 7 ( 5 ち乳酸菌共存 4 ), predominant org. なし 1 .

月経不整 5 例 : 乳酸菌 predominant 1, コリネ (V) predominant 1 (乳酸菌共存), Trichomonas vaginalis predominant 1 , predominant org. なし 2 .

閉経後12例：乳酸菌 predominant 2, コリネ(V) predominant 4 (乳酸菌共存 2 ), predominant org. なし 6 .

両側卵巣剔除後 4 例 : 乳酸菌 predominant $1, コ リ$ ネ (V) predominant 1 (乳酸菌共存), predominant org. なし 2 。

便宜上前 2 者を premenopausals，後 2 者を postmeno- 
第 5 表 卵巣機能と腟内細菌叢の predominant organisms

\begin{tabular}{l}
\multicolumn{2}{l|}{$\begin{array}{c}\text { predominaut } \\
\text { org. }\end{array}$} \\
$\begin{array}{c}\text { groups } \\
\text { of patients }\end{array}$
\end{tabular}

* Trichomonas vaginalis

pausals にまとめて示すと第 5 表のごとくになる，表の 理解を補うために試みに百分率をとつて作図したものを 添える (第 2 図).これによれば乳酸菌による胵粘膜 の predominancy が premenopausal stage から postmenopausal stage にかけて激減し，それとは逆に predominant org. を欠く情況が著しく増加することがわかる. 他 方コリネ(V)の predominancy はこの seriesに関し ては比較的安定な推移を示している. predominant org. を欠く情況とは換言すれば胵粘膜が常在細菌叢を定置せ しめるには十分でない環境へと劣化したことの反映で, かかる情況の者が閉経者を主体とするところからみてそ れは卵巣機能の衰えに相応するものと思われる。故に卵 巣機能の衰䫋はただに Hormone 依存性があるとされる 乳酸菌にとどまらず他の粘膜微生物にむ同様に及んでい ることを示するのである. 他方閉経期の前後を通じてコ リネ (V) predominant の情況が 比較的安定に 推移して いる事実は, この時期卵巣機能の衰えに相応する胵粘膜 細菌棲息環境の劣化に対しコリネ（V）が乳酸菌に比し てょり感受性のすくないことを示しており，乳酸菌の消 失が直ちに predominant org. を欠く情況につながるの ではなく，その間にコリネ（V）が predominancy を獲 得すべき必然性を示唆するものである，ただし predominant org. を欠く情況の11例について coryneform bacteria が存在したのは僅か 2 例にすぎなかつたことからみ てこの predominant org. の交代も恐らく一過性のもの であると思われる。そしてコリネ（V）も消裉したあと の胵粘膜は極めて少数の細菌がわづかに付着生残するに すぎない情況 (scanty material stage と仮称) にひきつ かれるものと考觉られる。

以上の過程を模式的に示せば, 卵巣機能が生じて以後
の腟内細菌叢の predominant organisms はつぎのごとく 推移する。

乳酸菌 predominant

$\downarrow \quad \mathrm{pH}: 4.0 \sim 4.2$

乳酸菌 predominant, コリネ $(\mathrm{V})$ 共存

$\downarrow \quad \mathrm{pH}: 4.0 \sim 4.2$

コリネ $(\mathrm{V})$ predominant, 乳酸菌共存

$\downarrow \quad \mathrm{pH}: \longleftarrow 4.8 \rightarrow$

コリネ (V) predominant, 乳酸菌消裉

$\downarrow \quad \mathrm{pH}: \leftarrow 4.8 \longrightarrow$

predominant org. なし (scanty material stage)

$\mathrm{pH}: \leftarrow 5.6 \rightarrow$

4. その他

a. Commeusals と判定された細菌種には大腸菌, Klebsiella，腸球菌などの腸内細菌，Staphylococcus epidesmidis， $\alpha$ または $\gamma$ レンサ球菌などのグラム陽性球 菌が屡々みられ，他方頻度のすくない分離菌種には Serratia, Enterobacter, Staphylococcus aureus などがあり， 嫌気性菌としては Propionibacterium が 1 株分離された だけであつた。これらは数的にはレンサ球菌を除けばい づれも散在性にしか存在しなかつた。また Neisseria， Haemophilus, Proteus，Pseudomonas などには遭遇しな かつた.

b . 最近 6 カ月間に尿路感染症罹患の前歴のあつた者 は 6 例で, 乳酸菌 predominant, コリネ(V) predominant および predominant org. を欠くの各情況に均しく 2 例づつ分布した。また尿路感染菌として最も頻度の大 さい大腸菌を保有した 7 例については predominant org. による上の 3 群に均しく 2 例づつ分布し（他の 1 例は Trichomonas vaginalis predominant の症例に存してい 
た)，そのうち尿路感染症前歷があつたのはコリネ(V) predominant および predominant org. を欠く情況に存 在していた各 1 例づつにすぎなかつた.

c 。ナマ標本において “Haemophilus vaginalis”腟 炎に pathognomonic であるとされた “clue cells”の所 見には特別の意義がみとめられなかつた。

\section{Coryneform bacteria による尿路感染症例について}

吾々は在来 coryneform bacteria 飞尿路感染菌とし ての積極的意義はないと考光ていたが, “Haemophilus vaginalis”に関する文献を捗班しているらちにこのもの が尿路感染菌たりらることを示唆する報告に接した ${ }^{21)}$. しかし Gardner らの精力的な仕事が専ら細菌性腔炎に 関するものであり，他の報告者のそれる尿道炎あるいは 産裖感染など両性の性路に関する病原性を論じたものば かりだつたので尿路起炎菌としての関心は稀薄であつ た。ところが偶々乳酸菌移植 series の症例の中で, 從 来尿路感染といえば殆んど純粋に急性腎孟炎にだけしか 罹患しなかつた者がはじめて典型的な急性膀胼炎を発し て来院した際にその起炎菌がコリネ（V）であつたこと から一般患者に和ける本菌の尿路感染症に対する役割り に注目していたところ, 引続さ 2 例の急性膀胱炎と各 1 例づつの単純性尿道炎拉よび炎症性 caruncle に本菌が 関与している症例に遭遇したのでそれらについて記述す る.

1. 28歳女性, 乳酸菌移植 series の No. 10 症例, 昭 和50年 6 月 9 日, 急性膀胼炎症状を発し近医の治療を5 けて一応寬解したが約10日常に再び同様の症状を発した ので来院した，尿は強度の溷濁あるも蛋白陰性, 赤血球 白血球多数, グラム陰性小桿菌が細胞内外にみられ（第 7 図), チョコレート寒天平板塗抹ローソク法 72時間 の 培養でコリネ $(\mathrm{V})$ の純培養をえた。同時に施行した一 般細菌培養検査で腸内細菌, グラム陽性球菌等すべて陰 性であつた. Thiophenicol 抌よび TC 各 5 日間づつの 経口投与で治癒したが, 爾来臸内容にコリネ（V）の predominancy がみられている。 そして現在にいたる 9 カ月間異常なく経過中である.移植による乳酸菌は昭和 48年10月 2 日に生着, 昭和 49 年 9 月 10 日まではその持続 をみとめた. 他方昭和 49 年 6 月 4 日以降グラム陽性物質 を菌体内に蔵するグラム陰性小桿菌が胵内容中に現れて 乳酸菌と共存するようになつたが, 前述の急性膀胱炎経 過後, 昭和 50 年 9 月 1 日の検查では乳酸菌の持続はな く, 昭和51年 2 月 2 日の最終検査でも同様で代つてコリ ネ (V) が predominant org. として存し, 少数の Sta- phylococcus epidermidis が共存するだけであつた。腔 内容中の “clue cells” 卅. 䐋 $\mathrm{pH}$ は4.2を示した.

このコリネ(V)和よび略々同じ頃(51．2１6）飞乳酸 菌移植 series の No. 20 症例から分離したコリネ $(\mathrm{V})$ は24〜48時間の若い培養から継代に成功し, 生化学的性 状による同定を試みた。前者はその過程中に死滅したが 後者については, 異染小体を蔵するグラム陽性桿菌, 10\%ウマ血寒上で $\alpha$ 溶血を示し, glucose, maltose, xylose を分解し, sucrose, lactose, trehalose, starch, arginine を分解せず, urease 陰性, nitrit 形成せず等の検 查結果から略々 “Haemophilus vaginalis” と同定され た. この症例は本菌分離に際して腟内容中には中等数に $\alpha$ レンサ球菌が共存し, 胵 $\mathrm{pH} は 5.6$, “scanty material stage” への移行期を思わせる情況であつた.

2. 45歳女性, 昭和50年10月 9 日夕刻より急性膀胱炎 の症状を発し，他医から 2 日分の投薬をらけたが効果を みないとして来院した，尿は強度に溷濁していたが白血 球は中等数, グラム陰性小桿菌のみ存す (第 8 図).チョ コレート寒天平板に塗抹ローソク法96時間の培養でコリ ネ（V）の純培養をえたが継代しえず．TC 7 日間の経 口投与で治療, 自覚症状は 3 日後に消失, 服薬終了後尿 飞炎症所見もなく細菌も陰性となつた。

3. 41歳女性, 2 週間来 の 排尿終末時疼痛之 尿意促 迫, 残尿感を訴兄て昭和 51 年 2 月 12 日来院, 尿は軽度に 溷濁, 炎症細胞は少数なるもグラム陰性小桿菌が多数存 在, 細菌培養は変形菌の swarming のために失敗した。 TC 7 日間の経口投与で治癒した.

4. 46 歳男性, 10 数年来毎年 $1 \sim 2$ 回単純性尿道炎を 起しつづけている.症候は常に温和で排膿のみ主訴とし て来院しているが分泌物中に特別な細菌種をみとめない ままに, ある時は放置, ある時は薬物経口投与〜尿道洗 涤を行つて寬解していたがこれらの治療を通じて局所治 療が最も効果が確実であつた。昭和50年 6 月 19 日，4〜 5 日来の排膿を主訴として来院したが尿道分泌は少量, 白血球井, 上皮細胞卅, 細胞内外飞多数の coryneform bacteria をみとめた. 尿道洗涤と TC 7 日間の投薬で治 癒した. 過去の経過からみて配偶者に同様の細菌が常在 すると考穴ているが未だ恰査の機会をもたない。

5. 40歳女性, 外尿道口の自発痛を訴元て来院, 他医 により Cephalosporin 含有の軟膏による局所治療をうけ たが効果なく電気治療をすすめられたとして当科受診. 昭和50年 7 月 1 日来院時, 外尿道口下壁より上方に向つ て尿道口を塞ぐように腫大した caruncle 表面から多量 
の排膿あり，鏡検により白血球井，グラム陰性小桿菌多 数が白血球細胞内外招よび上皮細胞上に蝟集す．培養は 陰性であつた。消炎剤と TC の併用で炎症症状は著明 に消裉した。 その後胵内容の検查で乳酸菌の predominancy がみとめられたのでそのまま放置して観察中であ る.

\section{考按}

反復性尿路感染症の処置については，その原因を特殊 な解剖学的または機能的な異常に帰してその対策を講ず るのも一法であるが，そのような事実の有無に不拘尿路 近傍の身体部位から尿路感染菌を可及的に排除して扔く のも一法である. 後の方式の処置をとる場合, 常時また は適宜抗菌性薬剂の継続使用が行われることが多いよう であるが，抗菌性薬剤の安直な使用は病原細菌の薬剤に 対する耐性賦与を容易ならしめ常に新たな抗菌性薬剤を 必要とするの連鎖を絶ちがたくし, かつは正常菌叢を破 壊するの危険性を有している. 吾々は尿路近傍の細菌環 境から尿路感染菌を永続的に排除する方法として尿路感 染菌とはなりにくい細菌種を以て該部の predominant org. とする試みをとつた。即ち更年前期の女性に多く みられる単純性尿路感染症の反復罹患素因が䐋粘膜の病 的細菌叢の成立にあることをたしかめ, その正常化のた めに培着乳酸菌生菌の胵粘膜移植を行つて所期の効果を 収めることができた訳であるが，個々の対象例に関して はやがて更年期を経て閉経期を迎えれば必然的に乳酸菌 は消裉すべき運命にあり，如何ほど本法が理想的に行わ れるにしてもその効果的適用には限界が存在する. 故に 引続き尿路近傍から尿路感染菌を排除しつづけるために は乳酸菌のように卵巣機能に依存するものではなく, し かも尿路感染症を炭起することがないよらな細菌種をそ の代替として利用することが必要となつてくる．このよ らな idea の医学的応用には，たと党ば膿皮症への対策 として Staphylococcus epidermidis S 6+の皮虐移植の 試みなどがある ${ }^{22)}$.いづれにせよある身体部位の細菌棲 息環境内である細菌種が predominancy を獲得するため には先づその環境内でその生存が適していることが第一 の前提であり，どんな微生物でもこの目的のために利用 しうる筈のものではない。そこでそのような organisms を探索する手がかりをらるために正常女性に打ける䐋 粘膜の organisms を検討したのであるが，その動態を しらべている過程で予め乳酸菌移植後に尿路感染症に関 する予後追跡中の症例で偶々 check されたグラム陰性 小桿菌が，実は正常過程に和いて乳酸菌の消裉後にそ
れに代つて “2nd acid prodncer”として腔内細菌叢の predominancy を獲得すべき細菌種であることの実態が 顕われてきた。腔内の coryneform bacteria 飞は真正の Haemophilus sp. ${ }^{1)}$, Corynebacterium sp. ${ }^{18)}$, 従来は嫌気 性 Corynebacterium とされていた Propionibacterium な ど種々の細菌種が含まれている筈である。たとえば乳 酸菌移植 series の No. 11のそれは Haemophilus parai nflnenzae であり, 正常女性検索 series の No. 1のそれ には当然 Propionibacterium も含まれているであろう し, No. 6のそれは catalase 反応陽性の真正の Corynebacterium であつた. 男性の性路 pathogens として checkされた heterogenous の Corynebacterium NSU と 称せられる細菌も怙とらくそれと無関係ではないである $5^{10) \sim 12)}$. しかしそれにも不拘胵内細菌叢中の coryneforim bacteria の殆どすべてが “Haemophilus vaginalis” であろらと考劣ることの理由は培養菌に打ける Edmunds の観察》 飞基いている. 彼は本菌の培養発育上の 至適 $\mathrm{pH}$ とは別にそれを継代する上での viability が low $\mathrm{pH}$ 環境に扮いて最大であることを指摘している. 一般に胵内細菌叢に括ける乳酸菌の生物学的意義はその るたらす low pH 環境が他の commensals の発育抑制 にはたらくためであると理解されているが, Edmunds の指摘が正しいならば “Haemophilus vaginalis”は 一般の細菌種が蒙る影響とは全く逆に乳酸菌の predominancy とその結果である䏽の low $\mathrm{pH}$ 環境がその胵 粘膜定着の前提として絶対に必要であることになるから である。この意味で, 吾々がこの仕事の最終段階で若い 培養からはじめて継代に成功したコリネ（V）の1株が 生化学的性状から “Haemophilus vaginalis” と同定さ れたことの意義は大きい，何故なら先に示した正常女性 の胵内細菌叢の predominant organisms の生理的な交代 現象にかかわる細菌を, 乳酸菌 乳酸菌 (+“Haemophilus vaginalis") $\rightarrow$ “Haemophilus vaginalis" (十乳酸 菌) $\rightarrow$ “Haemophilus vaginalis” $\rightarrow$ scanty と云うように書 き換えることが可能になるからである。“Haemophilus vaginalis”の hormone 依存性とついては有無の両論が あるがコリネ（V）の推移をみれば怙そらく hormone 依存性はないと考学てよいであろう。何故ならコリネ （V）の消褪は卵巣機能の衰頺による胵粘膜の細菌棲息 環境の劣化によるものでそれはコリネ（V）を含むすべ ての微生物に共通する事実であるからである。“Haemophilus vaginalis”も消裉してしまうような胵粘膜の細 菌棲息環境が極めて劣弱なものであれば，仮令そこに偶 
々尿路感染菌が生残持続しえてもそれが尿路感染症を生 起せしめるに足るだけの増殖は許容されないと考兄られ る (Stamey らの観察によれば胵内の尿路病原菌が感染 症を茇起せしめるに当つてはその前段階で胵内に大增殖 をみる由である） ${ }^{24)}$ ．そしてそのような事実が特定の細 菌による菌交代がなく，かつ大腸菌などの尿路病原菌を 保有していてもそれが值ちに反復性尿路感染素因に撃ら ぬ理由であるう。コリネ (V), 恐らくは“Haemophilus vaginalis”がどんな経路で胵粘膜に定着するのかはこの 探求では不詳であるが，多分それは乳酸菌定着後の相当 飞早い時期であると思われる. McFadyen $5^{211}$ は 1,000 例の妊婦の恥骨上穿刺尿の培養検査で159例に “Haemophilus vaginalis" の存在 (感染)を証明しているし， 吾々の症例中にも乳酸菌生着之略々同時期に “Haemophilus vaginalis” と同定されたコリネ（V）をみとめた 例（No. 20）があるから.

本来“Haemophilus vaginalis” が着目された契機は両 性の性路病原菌としてであるが'19)，中にはそれが全身感 染症を生起せしめたかに思わせる例外的な報告るある2). しかしその生起する症候は一般に極めて温和なもので人 によつては自己の病的情況を認識し党程度のもののよ らに思われる. 故に後の研究者達は Leopold の尿道炎 や前立腺炎, Gardner らの細菌性腔炎などの診断的根拠 に疑いを懐いていたようで, Edmunds にしてもその症 例に颃いて “Haemophilus vaginalis” の産褯感染症に 物ける病原性を規定するのに間接的な統計学的方法を援 用せざるをえなかつだ6)，故に本菌をはじめから無害な 常在菌であると見做す見解も当然に存在する ${ }^{4) 920)}$.た だし Criswell ら”は対数増殖期にある “Haemophilus vaginalis” の培養を直接胵粘膜に接種することにより彼 らの云う細菌性胵炎を高率に再現することができたとし ているので，本菌が他の commensals の共存を殆ど許さ ぬ程度に predominancy を獲ることはある程度の病的情 況に相応するのであろう。吾々の正常女性に和ける観察 では “Haemophilus vaginalis”と目されるコリネ (V) が predominant である場合の共存細菌は種類の上では 乳酸菌が predominant の場合とあまり異るところはな かつたが数的にはより多数にみられるのが常で，そのこ とが逆に本菌の有すべき病原性の発現を抑えるのに役立 つているのかもしれない，吾々の経験した性路感染症例 は温和なものであつた。純培養の状況で本菌が関与した 尿路感染 (急性膀胱炎) 症例はしかし一般の々れと症候 上の相異はなかつた。ただしこの件については在来見聞
するところがなかつたので論及を避け，ただその頻度の すくないことを予想するにとどめたい。

この org. が predominant である時期は乳酸菌が predominant である時期と胵粘膜の細菌棲息環境が “scanty” となる時期の谷間にあたり，Host は年龄的には40 歳前後で乳酸菌消褪に伴う low $\mathrm{pH}$ 環境による他の微 生物発育抑止能力の低下をみる反面, 卵巣機能や生殖能 力が尚も存在していることが多いのでもし尿路感染菌が そこに存在するならそれが感染症を生起するに足る程に 增殖しらる余地が残されている。これが腔粘膜に定着し ている病的細菌と反復性尿路感染素因とか相関しうる理 由であると考兄らる。

コリネ (V)，技とらく“Haemophilus vaginalis”が 2nd acid producer であるとはいつても，それが他の commensals の生存環境を破壊する程のるのではなく， まして抗菌性物質放出などの機構で他の增殖を積極的に 抑制しているとは思われない，その predominancy 獲得 の要因が先行の predominant org. である乳酸菌によつ て準備された環境条件に最も適合した生物学的性質を有 していたにすぎないと考光られるので，その“与兄られ た” predominancy が結果的には有限の環境内栄養物質 奪取によつて他の commensals の増殖余地を残さない, 従つて偶々尿路感染菌などが存在してもその増殖の余地 を比較的に奪つているのが実態であろ ${ }^{23)}$. 故にその predominancy は乳酸菌の場合に比してはるかに不安定 なものと考えられる。そしてそこにたとえば組織破壊性 の病的過程や広範囲抗生物質の濫用などの結果として病 的細菌叢成立のより高い可能性が生ずるものと思われ る.

“Haemophilus vaginalis” に関する細菌学的検索は Edmunds ${ }^{78)}$ そ拉いて最も著しく，その形態は coryneform の短桿菌, グラム染色性特よび溶血性は用いる培 養基によつて可変, 好適な培地（たと学ば Casman 培 地など）上での発育は24〜48時間の培養で辛うじてその 存在が認識できる程度の微小な透明集落しかつくらな い，栄養要求は厳しく赤血球実質の成分を必要とするが X因子，V因子他の Haemophilus sp. が要求するるの は必要でないと云う，Zinnemann ら ${ }^{25)}$ はその catalase 陰性の所見に苦虑しながらもC.parvum に近縁な Corynebacterium であることを示唆し，それに同調する研 究者もあるが5)，最近では細胞壁の物質構成から Actinomyces bovis に類縁の微生物であろうと考えられて いる ${ }^{17)}$. 本菌に関する細菌学的諸検索に抢ける最大の問 
題点はその研究者各個がとりあげている“Hamophilus vaginalis”なるものが実は必ずしも同一のものではない そいらことで，現段階で吾々はそれを単一の species で あるとするよりもむしろ heterogenous な細菌の一群で あると理解した方がよいと考㝋ている，その故に本文で はその記述にあたり終始“”印で囲うことにした。

以上正常女性飞打ける胵内細菌を検討して乳酸菌消裉 後にそれに代替しうる無害な細菌種を索めると云う当 初の目論見からは逸脱したが，腔内細菌環境に打ける predominant org. の一連の推移を窥らことができた。そ してそれを正常の過程であると見做すときに，人工的な 乳酸菌生菌の胵粘膜移植に引きつつい、て観察されたある 人達に括ける菌交代，拉よび他の人達に扣ける特殊な細 菌による菌交代がなく少数の尿路病原菌を保有しながら いづれも反復性尿路感染素因が復旧しない理由が，前者 にあつては乳酸菌消裉後は “Haemophilus vaginalis” へと predominancy が交代するという，また後者にあつ ては前述の菌交代の過程を経過したあとで “scanty material stage” 飞到るという，何れも正常胵粘膜に括け る細菌学的環境を模写するものであり，実に乳酸菌生菌 移植と云う処置が病的な腟内細菌環境を更年期の前後の 時期を cover して正常な過程に復㷌させたからである との認識に到達した。

このことは必然的に腔内細菌叢のみだれが反復性尿路 感染素因につながる人達に対する処置としての乳酸菌胵 移植は, 胵分泌物が量的に十分で豊富な細菌棲息環境を 支えている段階で適用され，その間は可及的に乳酸菌持 続が維持されるよう反復して計画され，もし乳酸菌が尧 われた情況になつた時に, “Haemophilus vaginalis”類 似の細菌による predominancy の交代がみられるなら， あるいは胵分泌物またはそれに含まれる有形成分が寡少 な “scanty material” の情況をみるのであれば乳酸菌移 植を繰返兄す必要はないと云う, 適用決定招よび適用中 止を規定する条件を提供するものとなるであろう。

\section{結語}

更年前期に多くみられる女性の反復性尿路感染素因に 対する処置として行つた乳酸菌生菌の胵粘膜移植の意義 を長期に亘る予後追跡によつて明確にし，その適用と適 用後の配慮について正常女性の更年前期から閉経後にい たる腔粘膜細菌動態の観察知見にてらし, 卵巣機能の存 続する間は可及的に乳酸菌持続が維持されるように考慮 し, 卵巣機能衰頽の時期に当つては乳酸菌から“Haemophilus vaginalis”と目される coryneform bacteria へと
腔内細菌叢の predominant org. の交代がみられるなら， または胵分泌物中の細胞成分拉よび細菌成分の極めて寡 少な情況をみるならばその処置の継続は必要がないと結 論した。

尿路感染症反復罹患の問題に着目するようになつて久 しいが，この間に在来この問題の捉え方が類型的かつ浅 薄なものであつたとの感懐が残つた．たとえばどのよう に反復すればそれが反復性の名に値するのかと云う事か ら先づ論ずる必要に迫られた。また吾々は反復性尿路感 染症を細菌学的に捉えようとしたが，実はその前の段階 として細菌種と尿路病原性の関係，発病と接種菌量の関 係，細菌の age（例へば培養に打ける lag phase とか logarithmic phase などの術語で表現されるような）と 病原性の関係，あるいは発病について個体の免疫反応関 与の関係など解明さるべき問題が多々存在した．それら を措いて常在細菌叢中に和ける病原細菌のあり方とい ら面での approach を試みたのであつたが，ここでも常 在菌叢そのものの動的な実態や生物学的意義について の具体的な知見はなきにひとしく，そのために“predominant organism” の把握の仕方も自ら顧みて極めて独 断的なるのにならざるをえなかつた。しかしまたそれは それなりに，在来性路病原菌乃至はそれに近い存在とし て捉えられてきた “Haemophilus vaginalis”につき， 尿路感染素因を indicator としてみれば，それが乳酸菌 消褪後の胵粘膜で一過性ながらも predominancy を獲得 することでその積極的な存在理由をみいだす結果にもつ ながつた．細菌学的検索については技術的に臨床検査部 門に多くを依存する情況で十分とは云光憾みがのこつ た。しかし臨床的研究は所詮は所属組織内の臨床検査部 門の能力範囲内で処理しらるところまで還元されるので なければその意義の大半が失われてしまう現代の赹勢で ああるので，その面での不徹底の譏りの幾分かは先に示 した“簡単な結論”によつて補うことができるものと信 じている.

稿を了るに当り “predominant organism” の解釈につ いて有益な御教示を賜つた半田晃久博士，種々゙御協力を 賜つた当院泌尿器科, 産婦人科, 中央検査室の医員, 看 護婦, 検查技師の各位ならびに順天堂大学病院中央検査 部の森伴雄氏に深甚の謝意を表します。

\section{文献}

1) Amies, C.R. and Jones, S.A.: Canad. J. Microbiol., 3, 579, 1957. (cit. Lapage, S.P.: Acta Path. Microbiol. Scand., 52, 34, 1961.) 
2) Carney, F.E.: Obstet. Gynec., 41, 78, 1973.

3) Criswell, B.S., Ladwig, C.L., Gardner, H.L. and Dukes, C.D.: Obstet. Gynec., 33, 195, 1969.

4) Dunkelberg, W.E., Hefner, J.D., Patow, W.E., Wyman, F.J. \& Orup, H.I.: Obstet. Gynec., 20. 629, 1962.

5) Dunkelberg, W.E., Skaggs, R. \& Kellog, D.S. : Amer. J. Clin. Path., 53, 370, 1970.

6) Edmunds, P.N.: J. Obstet. Gynec. Brit. Emp., 66, 917, 1959.

7) Edmunds, P.N.: J. Path. Bact., 79, 273, $1960(a)$.

8) Edmunds, P.N.: J. Path. Bact., 79, 325, 1960 (b).

9) Frampton, J. and Lee, Y.: J. Obstet. Gynec. Brit. Commonw., 71, 436, 1964.

10) Furness, G., Kamat, M.H., Kaminski, Z. and Seebode, J.J.: J. Urol., 106, 387 \& 557, 1971.

11) Furness, G. Kamat, M.H., Kaminski, Z. and Seebode, J.J.: Invest. Urol., 10, 387, 1973.

12) Furness, G. Kamat, M.H., Kaminski, Z. and Seebode, J.J.: Invest. Urol., 11, 486, 1974.

13) Gardner, H.L. and Dukes, C.D.: Am. J. Obstet. Gynec., 69, 962, 1955.

14) 清島茂寿, 山室美砂子, 稲田次郎：日泌尿会誌,
65, 685, 1974.

15) 清島茂寿：日本泌尿器科学会沖縄地方会設立流 念学術大会, 昭50.

16) Lapage, S.P.: Acta Path. Microbiol. Scand., 52, 34, 1961.

17) Lapage, S.P.: Bergey's Manual of Determinative Bacteriology, 8th Ed., p. 368, William \& Wilkins Co. Baltimore, 1975.

18) Laughton, N.: J. Hygine, 48, 346, 1950.

19) Leopold, S.: US Armed Forces Med. J., 4, 263, 1953. (cit. Lapage, S.P.: Acta Path. Microbiol. Scand., 52, 34, 1961).

20) Lewis, J.F. and O'Brien, S.M.: Am. J. Obstet. Gynec., 103, 843, 1969.

21) McFadyen, I.R. and Eykyn, S.J.: Lancet, 1, $1112,1968$.

22) Medical Tribune-London Bureau: Jap. Internat. Medical Tribune, 8, 50, 27, 1975.

23) Rosebury, T.: Bacterial and Mycotic Infections of Man, 4th Ed., p. 326, J.B. Lippincott Co. Philadelphia, 1965.

24) Stamey, T.A., Timothy, M., Millar, M. and Mihara, G.: California Med., 115, 1, 1, 1971.

25) Zinnemann, T. and Turner, G.C.: J. Path. Bact., 85, 213, 1963.

(1976年6月11日受付) 